\title{
Characterization of the Fungal Community Associated with Root, Crown, and Vascular Symptoms in an Undiagnosed Yield Decline of Winter Squash
}

\author{
Hannah M. Rivedal, ${ }^{1, \dagger}$ Alexandra G. Stone, ${ }^{2}$ Paul M. Severns, ${ }^{1,3}$ and Kenneth B. Johnson ${ }^{1}$ \\ ${ }^{1}$ Department of Botany and Plant Pathology, Oregon State University, 2082 Cordley Hall, Corvallis, OR 97331 \\ ${ }^{2}$ Department of Horticulture, Oregon State University, 4017 Agriculture and Life Sciences Building, Corvallis, OR 97331 \\ ${ }^{3}$ Department of Botany and Plant Pathology, University of Georgia, Miller Plant Science 2315, Athens, GA 30602
}

Accepted for publication 7 November 2019.

\begin{tabular}{|c|c|}
\hline \multicolumn{2}{|c|}{ ABSTRACT } \\
\hline $\begin{array}{l}\text { Winter squash (Cucurbita maxima) is produced in Oregon's } \\
\text { Willamette Valley for edible seeds, processing, and fresh markets. } \\
\text { Recently, prominent cultivar Golden Delicious has experienced } \\
\text { significant yield losses due to a soilborne disease. Symptoms } \\
\text { include stunting, root and crown rot, vascular discoloration, and } \\
\text { late-season vine collapse. To identify potential causal pathogens, } \\
64 \text { fields were surveyed during } 2014 \text { to } 2016 \text { to characterize the } \\
\text { fungal community associated with surface-disinfested root, crown, } \\
\text { and stem tissue of diseased and healthy squash. Over } 10,000 \\
\text { fungal isolates were identified morphologically, and } 1,783 \text { isolates } \\
\text { were identified to species by sequencing of internal transcribed } \\
\text { spacer and translation elongation factor } 1 \text { alpha genomic regions. } \\
\text { Fungal communities were analyzed for association with the } \\
\text { presence or absence of field symptoms using multivariate } \\
\text { community analyses (indicator species analysis, multiresponse } \\
\text { permutation procedure, and nonmetric multidimensional scaling). }\end{array}$ & $\begin{array}{l}\text { Although no fungal species were consistently associated with } \\
\text { disease, five species were consistently isolated from plants } \\
\text { regardless of the presence of symptoms and were capable of } \\
\text { causing disease in a greenhouse pathogenicity trial: Fusarium } \\
\text { oxysporum, F. solani, F. culmorum, Plectosphaerella cucumerina, } \\
\text { and Setophoma terrestris. Results from community analyses } \\
\text { confirmed that some fungi were more common in specific } \\
\text { tissues (e.g., P. cucumerina in stems and crown, F. solani in roots } \\
\text { and crown). Symptom severity tended to be greater in fields with a } \\
\text { prior history of squash production, although a few fields with no } \\
\text { prior history of squash had above average symptom ratings. The } \\
\text { results from this study suggest that the five most common fungi } \\
\text { may take on greater disease significance when they co-occur in a } \\
\text { host. } \\
\text { Keywords: agriculture, ecology, plant pathology }\end{array}$ \\
\hline
\end{tabular}

Winter squash (Cucurbita maxima) is grown in Oregon's Willamette Valley for edible seed production, frozen food processing, and fresh market production, which together comprise an annual 7-million-dollar industry (Taylor and Losh 2018). Over 2 decades, industry personnel and extension agents have reported an emerging soilborne disease problem in winter squash with symptoms that include root and crown rot, vascular discoloration, stunting, and reduced fruit size and seed yield. In extreme cases, a

${ }^{\dagger}$ Corresponding author: H. M. Rivedal; rivedalh@oregonstate.edu

Funding: Partial funding was provided by USDA NIFA Western SARE project SW15-021.

*The $\boldsymbol{e}$-Xtra logo stands for "electronic extra" and indicates that three supplementary appendixes are published online.

The author(s) declare no conflict of interest.

(C) 2020 The American Phytopathological Society late-season vine collapse has caused crop failures. National Agricultural Statistical Service surveys (USDA/NASS QuickStats Adhoc Query Tool at https://quickstats.nass.usda.gov/) reported yields of greater than 15 tons per acre in 2000 and 2001, but an average of only 9 tons per acre from 2002 to 2014. In 2015, production in mostly new regions of the valley had yields over 15 tons per acre, but these regions are at increasing distances from the processing facilities. Research that could potentially ameliorate diseaseinduced production losses in winter squash is hampered by a lack of understanding of causal agents of the yield decline problem.

Soilborne fungal pathogens have plagued cucurbit production in different regions of the world. In some cases, cucurbit diseases are attributable to a single pathogen, while in others, more complex pathogen interactions exist. Races of Fusarium solani f. sp. cucurbitae have been identified as the causal agent of cortical stem rot and fruit rot in pumpkin and winter squash species in California and Pennsylvania (Mehl and Epstein 2007; Samac and Leong 1989). F. oxysporum f. sp. melonis has been identified as the causal agent of melon collapse and root rot in California and New 
York (Gwynne et al. 1997; Zuniga et al. 1997). In California and Texas, both $F$. oxysporum and $F$. solani have been found to be causal agents of fruit and root rots of muskmelon species (Champaco et al. 1993; Mertely et al. 1991). And these same Fusarium species have been found in complex with other fungal pathogens such as Acremonium cucurbitacearum, Monosporascus cannonballus, and Pythium spp. causing melon collapse (Aegerter et al. 2000; Martyn and Miller 1996). In Japan, winter squash (C. moschata) has been damaged by pink root rot caused by Setophoma terrestris (Ikeda et al. 2012). In Europe, melon vine collapse caused yield reductions and was attributed to A. cucurbitacearum, M. cannonballus, Plectosphaerella cucumerina, and Rhyzopycnis vagum (Carlucci et al. 2012; Chilosi et al. 2008). However, in Italy and Spain, crown rot and vine collapse of zucchini and winter squash has been attributed to $F$. solani and/or $P$. cucumerina (García-Jiménez et al. 1997; Vitale et al. 2007). Commonly, these research reports describe symptoms similar to those observed in Oregon-grown winter squash, and frequently more than one fungal pathogen is associated with the symptoms, which is indicative of a pathogen complex (Fitt et al. 2006; Lamichhane and Venturi 2015; Le May et al. 2009).

Winter squash, though an important Oregon crop, has not received the research attention of other cucurbit species. Of critical importance is to determine whether the disease is caused by a single or multiple causal agents and which cultivation practices are associated with disease severity. A 3-year survey of commercial squash fields was conducted to obtain information on the culturable fungi associated with symptoms in roots, crowns, and vascular stem tissues of squash plants. Multivariate statistics, commonly used in community ecology and diversity studies (McCune and Mefford 1999), were employed to evaluate the pool of potential causal agents with disease symptoms and to identify grower practices that may be associated with disease incidence. Specific questions that were asked to gain an understanding of this pathosystem included the following: (i) Is there a consistent set of fungal species associated with symptoms of vine collapse and root rot of winter squash? (ii) Are these fungal species unique to C. maxima, or do other commercially grown cucurbit species also harbor these fungi? (iii) Are the same fungi found in the stem, crown, and root tissue? And (iv) is there a difference between species associated with symptoms in plants grown under a processed vegetable rotation, a fresh market rotation, a mint rotation, a fallow rotation, or a grass seed rotation? Ultimately, the survey results were expected to create a shortlist of potential pathogenic agents for further evaluation in pathogenicity tests to fulfill Koch's postulates.

\section{MATERIALS AND METHODS}

Two approaches were used to survey squash fields. In 2014 and 2015, nonrandom samples of C. maxima, C. moschata, C. pepo, and Cucumis sativus were made to characterize the fungal communities associated with symptomatic and asymptomatic plants and to identify the potential causal agents of disease. In 2016, the scope was focused on $C$. maxima only and involved plants sampled randomly to examine disease symptom occurrence and severity in relation to the fungi present in squash tissues and to crop rotation history. Throughout, the survey approaches were kept separate by year.

Field survey to characterize fungal community associated with Willamette Valley cucurbits (2014-2015). Cucurbit plants were collected from 12 commercial squash fields in 2014 and seven fields in 2015 located in Benton, Lane, Linn, Marion, and Yamhill counties in Oregon. Most fields (80\%) were planted for processing, whereas the others were planted for local fresh markets. Processing fields ranged from 5.3 to 32.4 ha and fresh market fields were 1.2 to 3.2 ha. From both processing and fresh market fields, four different cucurbit species were sampled: C. maxima, C. moschata, C. pepo, and Cucumis sativus (Table 1). From each field, an average of 20 plants were collected from early July to early September (Table 1); the number of plants collected ranged from 4 to 30 with more samples from fields with symptoms, including wilting, stunting, and/or chlorosis. Plants were collected throughout the fields to include both asymptomatic and symptomatic plants. Plants were dug to preserve as many roots as possible, and vines were trimmed to a length of 0.3 to $0.6 \mathrm{~m}$ proximal to the crown.

After collection, plants were washed to remove soil and then assessed for symptoms by cutting open the roots, crown $(5-\mathrm{cm}$ section of stem immediately adjacent to the roots), and stem $(>5 \mathrm{~cm}$ from the roots, but below the first branch). In 2014, plants were rated symptomatic or asymptomatic depending on the presence of discoloration or rot. In 2015, a symptom severity rating scale was developed where plants were rated from 1 to 4 for roots, crowns, or stem vascular tissue: 1, no yellowing/discoloration; 2, localized yellow to orange discoloration; 3 , localized orange to brown discoloration; and 4, complete discoloration. Plants with two tissue ratings of 2 or higher or at least one rating of 3 or 4 were considered

TABLE 1

Summary of winter squash (Cucurbita spp.) fields surveyed from Oregon's Willamette Valley from 2014 to 2016 growing seasons to characterize fungal communities associated with healthy and diseased squash tissues

\begin{tabular}{|c|c|c|c|c|c|c|c|c|c|c|c|c|c|}
\hline \multirow[b]{2}{*}{ Year } & \multirow[b]{2}{*}{$\begin{array}{l}\text { Number } \\
\text { of fields }\end{array}$} & \multicolumn{3}{|c|}{ Field history of cucurbit production } & \multirow[b]{2}{*}{$\begin{array}{l}\text { Number of } \\
\text { plants } \\
\text { collected }^{\mathrm{x}}\end{array}$} & \multirow[b]{2}{*}{$\begin{array}{l}\text { Healthy } \\
\text { plants }^{y}\end{array}$} & \multirow[b]{2}{*}{$\begin{array}{l}\text { Diseased } \\
\text { plants }^{\mathrm{z}}\end{array}$} & \multicolumn{4}{|c|}{$\begin{array}{c}\text { Number of plants of each } \\
\text { cucurbit species }\end{array}$} & \multirow{2}{*}{$\begin{array}{l}\text { Number of } \\
\text { isolates } \\
\text { morphologically } \\
\text { identified }\end{array}$} & \multirow{2}{*}{$\begin{array}{c}\text { Number of } \\
\text { isolates } \\
\text { molecularly } \\
\text { identified }\end{array}$} \\
\hline & & $\begin{array}{c}\text { History } \\
\text { of } \\
\text { disease }^{v}\end{array}$ & $\begin{array}{c}\text { Never } \\
\text { planted in } \\
\text { cucurbits }^{w}\end{array}$ & $\begin{array}{l}\text { Symptom } \\
\text { development } \\
\text { in season }\end{array}$ & & & & $\begin{array}{c}C . \\
\text { maxima }\end{array}$ & $\begin{array}{l}\text { Cucumis } \\
\text { sativus }\end{array}$ & $\begin{array}{c}\text { C. } \\
\text { moschata }\end{array}$ & $\begin{array}{c}\text { C. } \\
\text { pepo }\end{array}$ & & \\
\hline 2014 & 12 & 9 & 3 & 10 & 282 & 101 & 181 & 200 & 20 & 27 & 35 & 4,244 & 1,399 \\
\hline 2015 & 7 & 5 & 0 & 6 & 94 & 55 & 39 & 34 & 11 & 42 & 7 & 2,050 & 121 \\
\hline 2016 & 49 & 10 & 25 & 43 & 1,632 & 923 & 611 & 1,632 & 0 & 0 & 0 & 4,497 & 263 \\
\hline
\end{tabular}

$\checkmark$ Fields with a history of disease according to crop consultants.

w Never planted in cucurbits according to 5-year rotation history obtained from growers and crop consultants.

x Number of plants collected in each growing season. In 2014, 83 plants were collected from fresh market fields and 199 plants were collected from processing crop fields. In 2015, 33 plants were collected from fresh market fields and 61 plants were collected from processing crop fields.

y In 2014, plants were classified as healthy if they did not exhibit any stem discoloration, crown rot, or root rot symptoms. In 2015 and 2016 , plants with all disease severity ratings of 1 or only one rating of 2 were classified as healthy.

z In 2014, plants were classified as diseased if they showed any stem discoloration, crown rot, or root rot symptoms. In 2015 and 2016 , plants with at least two disease severity ratings of 2 or at least one rating of 3 or 4 were classified as diseased. 
symptomatic, and plants with all 1 ratings or only one rating of 2 were considered asymptomatic.

Fungal isolation and identification. Fungi were isolated from the vascular tissue of the roots, crowns, and stems. In a laminar flow hood, 1- to 2-mm cross sections of each tissue were cut with a flamed knife and then quartered into 1- to 2-mm wedges that were disinfested in a $1.13 \% \mathrm{NaOCl}$ solution for $2 \mathrm{~min}$, rinsed once in sterile water for $30 \mathrm{~s}$, and dry blotted on a paper towel. Four pieces from each tissue type were placed equidistantly apart on plates of 1/8th strength potato dextrose agar (PDA; $4.875 \mathrm{~g}$ of PDA, $12 \mathrm{~g}$ of Bacto agar, and 1 liter of water) (Difco, Franklin Lakes, NJ) in 9-cm Petri plates amended with chlortetracycline at $20 \mu \mathrm{g} / \mathrm{ml}$ and streptomycin at $50 \mu \mathrm{g} / \mathrm{ml}$ (all subsequent media utilized in this study were amended with these antibiotics).

Plates were incubated in crisper boxes at 22 to $25^{\circ} \mathrm{C}$ for 5 to 7 days in a $12 \mathrm{~h}$ light/dark cycle. Following incubation, plates with fungi were photographed, and fungi present were identified to species morphologically (Dugan 2006; Leslie and Summerell 2006) (data on morphological identities were reconfirmed in 2018 by review of the photographs). A representative subset of visually identified fungi (two and six per plant) were transferred to fresh $1 /$ 8th PDA to prepare for molecular identification. To ensure pure cultures, all isolates were single-spored following the Fusarium Laboratory Manual protocol (Leslie and Summerell 2006). Cultures were maintained on Spezieller Nährstoffarmer agar (SNA). Fungi that did not produce spores in culture were examined under a dissecting microscope for individual growing hyphal tips that were extracted once and maintained on SNA. These non-spore-forming cultures represented approximately $2 \%$ of the total pure cultures.

In total, 1,520 pure (single spore or hyphal tip) cultures that were representative of the diversity of fungal cultures identified morphologically were subjected to DNA sequencing and identification. In 2014, DNA was extracted with DNeasy Plant Mini Kit (Qiagen, Hilden, Germany) (Griffin et al. 2002), and in 2015, with InstaGene Matrix (Bio-Rad Laboratories, Hercules, CA) (Ciardo et al. 2006). Extracted DNA was subjected to PCR of the internal transcribed spacer (ITS) region (White et al. 1990) and translation elongation factor 1 alpha (EF1 $\alpha)$ gene region (Leslie and Summerell 2006). PCR amplicons were cleaned with ExoSapIT (Affymetrix, Santa Clara, CA) and submitted to the Oregon State University Center for Genome Research and Biocomputing (CGRB) for sequencing. Sequences were entered into the NCBI BLAST and FusariumID databases for identification (accession numbers MN521703 to MN521808, MN521834 to MN523210, and MN553564 to MN553577). A sequence match of greater than $97 \%$ similarity was considered indicative of a species in this study. A sequence match less than $97 \%$ similarity was categorized into genus only.

Statistical analysis of 2014-2015 survey data. Data on isolate identity were subjected to multivariate statistical analyses to characterize associations among fungal species and the host tissues from which they were recovered. Identities based on morphology were analyzed separately from those based on sequence analysis. Morphological identifications included a larger number of fungal isolates with a relatively narrower scope of identification due to limitations of morphological identification methods, and the molecular identifications included a smaller number of isolates recovered from a fewer number of plants but had a broader scope of identification (Supplementary Appendix S1).

Nonmetric multidimensional scaling (NMS or NMDS), an ordination analysis, was used to evaluate whether the fungal community differed between symptomatic and healthy plants, cucurbit species sampled, plant tissue type, and processed vegetable versus fresh market production fields. This method does not assume linear relationships among variables and allows for comparison of categorical variables
(Kruskal 1964; Mather 1976; McCune and Grace 2002). Morphological identifications were entered into a primary species matrix that contained a row for each plant collected (376) and a column for fungal species (15) identified through visual evaluations in 2014 and 2015. Counts of each fungus per plant were entered into the corresponding matrix cell. A secondary trait matrix was created with the same number of rows (plants) and 14 columns of grouping variables: six categorical (field, cultivar, year, diseased [yes or no], cucurbit species, and crop purpose) and eight quantitative variables (0 or 1 response): symptomatic, asymptomatic, C. maxima, C. moschata, C. pepo, Cucumis sativus, processing, or fresh market. Primary and secondary matrices were similarly created for each specific tissue of isolate recovery (831 rows); in this case; the secondary matrix had the previous 14 columns plus an additional 4 columns for tissue type: one categorical variable (tissue) and three quantitative variables (stem, crown, and root). Analogous matrices for molecular identifications were created and were analyzed separately from the morphological data. The molecular primary matrix had 337 plant rows and 86 columns of unique fungal species; the matrix had 449 tissue rows and 86 fungal species. Secondary matrices were the same as described above.

After creating matrices, outlier analysis utilizing Sørensen distance measurements was conducted in PC-ORD (Version 7, MjM Software, Gleneden Beach, OR) to remove plants with fungal communities greater than two standard deviations from the grand mean, as such extreme statistical outliers may obscure important biological associations in these kinds of multivariate analyses (McCune and Grace 2002). From the morphological dataset, 39 plant rows and 185 tissue rows were removed. From the molecular dataset, 67 plant rows and 5 tissue rows were removed. Additionally, in the molecular dataset, those fungal species that only had one or two total counts were removed (51 species). The NMS analysis was run in PC-ORD using the "medium" autopilot settings in Sørensen distance (50 randomized runs and 50 real runs, penalizing for ties, which provides a more conservative result). Following ordination construction based on the primary matrix, variables from the secondary matrix were overlaid to identify groupings related to the fungal community.

To estimate the strength of association between a potential causal agent and a category of interest (diseased or healthy, cucurbit species, farm type, or tissue type), indicator species analysis (ISA) was used. With ISA, each species receives an indicator value that is the product of consistent presence in an environmental group and frequency of occurrence in that group; i.e., a species has a perfect indicator (value $=$ 100) when it is always present in a group and exclusive to that group (Dufrene and Legendre 1997; McCune and Grace 2002). Consistent presence is calculated as total occurrences of species in a group divided by total occurrences in all groups, and species frequency of occurrence is the proportion of sample units in each group that contain that species. The same datasets described for NMS were used for ISA and utilized the same outlier analysis. ISA was run in PC-ORD with Monte Carlo estimation from 4,999 random runs.

Pathogenicity testing. For fungal species isolated frequently, greenhouse evaluations of pathogenicity were conducted during the winter of 2016-17. Five spore-forming fungi were selected for this evaluation: F. oxysporum, F. solani, F. culmorum, Plectosphaerella cucumerina, and Setophoma terrestris. Six individual isolates of each fungal species collected from different fields were cultured individually in $175 \mathrm{ml}$ of potato dextrose broth for 7 days at $22^{\circ} \mathrm{C}$ on a shaker at $400 \mathrm{rpm}$. Inocula were prepared following methods of Punja and Parker (2000). Conidia concentrations were adjusted to between $10^{5}$ and $10^{7}$ spores per ml with aid of a hemocytometer (confirmed by dilution plating onto PDA). In a greenhouse, 3-weekold seedlings of $C$. maxima 'Golden Delicious' grown in Sunshine Professional Mix 4 (Sun Gro Horticulture, Agawam, MA) were uprooted and washed. Roots were trimmed to 5-cm in length and 
placed into a spore suspension (hand shaken to resuspend spores) or broth-only control for $3 \mathrm{~min}$. Inoculated seedlings, three per isolate and 18 per fungal species or control, were replanted in 3.8-liter pots and arranged in a completely randomized design on benches. The greenhouse was maintained at $27^{\circ} \mathrm{C}$ with a 12-h light/dark cycle for 8 weeks. As plants exhibited symptoms or after 8 weeks of growth, they were destructively harvested. Harvested plants were washed, rated for symptoms in root, crown, and stem tissues on the 1 to 4 rating scale described above. Each of the tissues also were cut into small pieces, surface disinfested, and plated onto PDA to attempt to reisolate inoculated fungi. Recovered isolates were identified based on morphology and ITS sequences. This experiment was conducted once.

Symptom severity ratings were analyzed using multiresponse permutation procedure (MRPP), which is a test for group membership based on nonparametric multivariate data (McCune and Grace 2002). Each of the 108 plants treated with one of the five fungal species or a control were entered into a primary matrix that had a column for each tissue rating. A secondary matrix had the same list of plants and two categorical variables: fungal species and isolate. MRPP utilized the two matrices to calculate the multivariate distance similarity among samples within each group and to

TABLE 2

Fungal species isolated from Cucurbita maxima, C. moschata, C. pepo, and Cucumis sativus plants collected from fields in Oregon's Willamette Valley during the summers of 2014 and 2015 summarized by method of isolate identification ${ }^{v}$

\begin{tabular}{|c|c|c|c|c|c|c|c|c|c|c|c|c|c|c|}
\hline \multirow[b]{3}{*}{$\begin{array}{l}\text { Data set } \\
\text { and year }\end{array}$} & \multirow[b]{3}{*}{ Species } & \multirow[b]{3}{*}{$\begin{array}{l}\text { Total } \\
\text { count }\end{array}$} & \multirow[b]{3}{*}{$\begin{array}{c}\text { Total } \\
\text { percent }\end{array}$} & \multirow{2}{*}{\multicolumn{2}{|c|}{ Number from }} & \multirow{2}{*}{\multicolumn{4}{|c|}{ Number of plants of each cucurbit species ${ }^{w}$}} & \multicolumn{5}{|c|}{ Number from } \\
\hline & & & & & & & & & & \multirow[b]{2}{*}{$\begin{array}{l}\text { Processing } \\
\text { squash }\end{array}$} & \multirow{2}{*}{$\begin{array}{l}\text { Fresh } \\
\text { market } \\
\text { squash }\end{array}$} & \multirow[b]{2}{*}{ Stem } & \multirow[b]{2}{*}{ Crown } & \multirow[b]{2}{*}{ Root } \\
\hline & & & & $\begin{array}{l}\text { Diseased } \\
\text { plants }^{\mathrm{x}}\end{array}$ & $\begin{array}{l}\text { Healthy } \\
\text { plants }^{y}\end{array}$ & C. maxima & C. moschata & $\begin{array}{l}\text { Cucumis } \\
\text { sativus }\end{array}$ & C. pepo & & & & & \\
\hline \multicolumn{15}{|c|}{ Morphological } \\
\hline \multirow[t]{8}{*}{2014} & $\begin{array}{c}\text { Plectosphaerella } \\
\text { cucumerina }\end{array}$ & 719 & 17 & 495 & 224 & 461 & 68 & 62 & 128 & 307 & 412 & 196 & 382 & 147 \\
\hline & $\begin{array}{l}\text { Fusarium } \\
\text { oxysporum }\end{array}$ & 887 & 21 & 646 & 241 & 625 & 118 & 57 & 87 & 684 & 203 & 62 & 431 & 389 \\
\hline & F. solani & 532 & 13 & 417 & 115 & 245 & 35 & 89 & 163 & 148 & 384 & 37 & 231 & 266 \\
\hline & F. culmorum & 71 & 2 & 40 & 31 & 46 & 4 & 2 & 19 & 43 & 28 & 22 & 24 & 25 \\
\hline & Other Fusarium sp. & 348 & 8 & 245 & 103 & 200 & 82 & 23 & 43 & 208 & 140 & 100 & 139 & 100 \\
\hline & $\begin{array}{c}\text { Setophoma } \\
\text { terrestris }\end{array}$ & 152 & 4 & 114 & 38 & 103 & 37 & 0 & 12 & 133 & 19 & 5 & 101 & 46 \\
\hline & Other fungi & 1,535 & 36 & 1,109 & 426 & 998 & 196 & 87 & 254 & 775 & 760 & 458 & 489 & 593 \\
\hline & Total & 4,244 & 100 & 3,066 & 1,178 & 2,678 & 540 & 320 & 706 & 2,298 & 1,946 & 880 & 1,797 & 1,566 \\
\hline \multirow[t]{8}{*}{2015} & P. cucumerina & 536 & 26 & 260 & 276 & 143 & 296 & 35 & 62 & 275 & 261 & 195 & 204 & 137 \\
\hline & F. oxysporum & 465 & 23 & 180 & 285 & 219 & 165 & 60 & 21 & 368 & 97 & 52 & 210 & 203 \\
\hline & F. solani & 282 & 14 & 127 & 155 & 117 & 105 & 38 & 22 & 184 & 98 & 64 & 124 & 94 \\
\hline & F. culmorum & 42 & 2 & 20 & 22 & 9 & 23 & 5 & 5 & 29 & 13 & 14 & 15 & 13 \\
\hline & Other Fusarium sp. & 210 & 10 & 72 & 138 & 100 & 87 & 7 & 16 & 175 & 35 & 61 & 90 & 59 \\
\hline & S. terrestris & 81 & 4 & 26 & 55 & 43 & 38 & 0 & 0 & 81 & 0 & 4 & 56 & 21 \\
\hline & Other fungi & 434 & 21 & 170 & 264 & 136 & 212 & 56 & 30 & 234 & 200 & 163 & 112 & 159 \\
\hline & Total & 2,050 & 100 & 855 & 1,195 & 767 & 926 & 201 & 156 & 1,346 & 704 & 553 & 811 & 686 \\
\hline \multicolumn{15}{|c|}{ Molecular $^{2}$} \\
\hline \multirow[t]{8}{*}{2014} & $\begin{array}{l}\text { Plectosphaerella } \\
\text { cucumerina }\end{array}$ & 265 & 19 & 92 & 173 & 184 & 1 & 20 & 60 & 71 & 194 & 65 & 157 & 43 \\
\hline & $\begin{array}{l}\text { Fusarium } \\
\text { oxysporum }\end{array}$ & 351 & 25 & 135 & 216 & 253 & 10 & 39 & 49 & 213 & 138 & 24 & 194 & 133 \\
\hline & F. solani & 174 & 12 & 54 & 120 & 85 & 3 & 43 & 43 & 41 & 133 & 17 & 68 & 89 \\
\hline & F. culmorum & 19 & 1 & 7 & 12 & 15 & 1 & 0 & 3 & 12 & 7 & 1 & 7 & 11 \\
\hline & Other Fusarium sp. & 180 & 13 & 79 & 101 & 120 & 7 & 21 & 31 & 76 & 104 & 50 & 90 & 40 \\
\hline & $\begin{array}{c}\text { Setophoma } \\
\text { terrestris }\end{array}$ & 58 & 4 & 27 & 31 & 46 & 6 & 0 & 6 & 50 & 8 & 7 & 37 & 14 \\
\hline & Other fungi & 352 & 26 & 146 & 206 & 242 & 7 & 44 & 60 & 147 & 205 & 107 & 133 & 112 \\
\hline & Total & 1,399 & 100 & 540 & 859 & 945 & 35 & 167 & 252 & 610 & 789 & 271 & 686 & 442 \\
\hline \multirow[t]{8}{*}{2015} & P. cucumerina & 40 & 33 & 31 & 9 & 10 & 12 & 4 & 11 & 8 & 32 & 19 & 16 & 5 \\
\hline & F. oxysporum & 45 & 37 & 32 & 13 & 19 & 10 & 8 & 2 & 27 & 18 & 1 & 23 & 21 \\
\hline & F. solani & 12 & 10 & 9 & 3 & 7 & 2 & 2 & 0 & 8 & 4 & 1 & 7 & 4 \\
\hline & F. culmorum & 2 & 2 & 2 & 0 & 0 & 0 & 1 & 0 & 0 & 2 & 1 & 1 & 0 \\
\hline & Other Fusarium sp. & 13 & 11 & 9 & 4 & 7 & 3 & 1 & 0 & 10 & 3 & 2 & 8 & 3 \\
\hline & S. terrestris & 2 & 2 & 2 & 0 & 1 & 1 & 0 & 0 & 2 & 0 & 0 & 1 & 1 \\
\hline & Other fungi & 7 & 5 & 4 & 3 & 2 & 3 & 2 & 0 & 2 & 4 & 3 & 2 & 2 \\
\hline & Total & 121 & 100 & 89 & 32 & 46 & 31 & 18 & 13 & 57 & 64 & 27 & 58 & 36 \\
\hline
\end{tabular}

$\checkmark$ Supplementary Appendix S1 provides details of all other fungi identified.

w Supplementary Appendix S2 provides details of all cucurbit cultivars sampled.

x In 2014, plants were classified as diseased if they showed any stem discoloration, crown rot, or root rot symptoms. In 2015 and 2016 , plants with at least two disease severity ratings of 2 or at least one rating of 3 or 4 were classified as diseased.

y In 2014, plants were classified as healthy if they did not exhibit any stem discoloration, crown rot, or root rot symptoms. In 2015 and 2016 , plants with all disease severity ratings of 1 or only one rating of 2 were classified as healthy.

$z$ Isolates identified through sequencing of ITS and EF1 $\alpha$ genes. 
compare the similarities to the other groups with a chance-corrected $t$ statistic (McCune and Grace 2002; Mielke et al. 1981). MRPP was used to assess whether the fungal species treatment was associated with differences in symptom severity compared with the broth-only control treated plants. The level of significance for $P$ values was adjusted for 15 comparisons using a Bonferroni correction and set to a new significance level of 0.0033 (Shaffer 1995; Steel et al. 1997).

2016 field survey of commercially grown $C$. maxima 'Golden Delicious' plants. A third year of survey was conducted in 2016 with a redesigned purpose. The objective was to sample plants from multiple, unbiased points within fields to obtain an estimate of how frequently potential pathogens identified from the previous surveys could be detected, and to assess if rotation history was related to observed symptom severity and frequency of fungal species recovery. Forty-nine fields of $C$. maxima 'Golden Delicious' located in Benton, Lane, Linn, Marion, and Yamhill counties in Oregon were selected for sampling with assistance from local crop advisers. Field sizes ranged from 3 to 138 ha with most fields between 10 and 30 ha. All fields were sampled near crop maturity (between 2 and 11 September). For every 10 ha in a field, a random point was generated using PlotHound software (SilviaTerra, San Francisco, CA), and at each point, 20 plants were collected at 7.6-m intervals (i.e., 152-m transect). For smaller fields ( 3 to $8 \mathrm{ha}$ ), two points were obtained from PlotHound and a 10plant sample was collected from each point, totaling 20 plants. One exceptionally large field ( $138 \mathrm{ha}$ ) was sampled at only six points. As in previous seasons, plants were collected to preserve roots, and vines were trimmed to 0.3 to $0.6 \mathrm{~m}$ above the crown.

Plants were washed and evaluated for symptoms with the 1 to 4 rating scale developed in 2015. Three representative plants per 20plant sample and two plants per 10-plant sample were processed for fungal isolation as described previously. After incubation on $1 / 8$ th

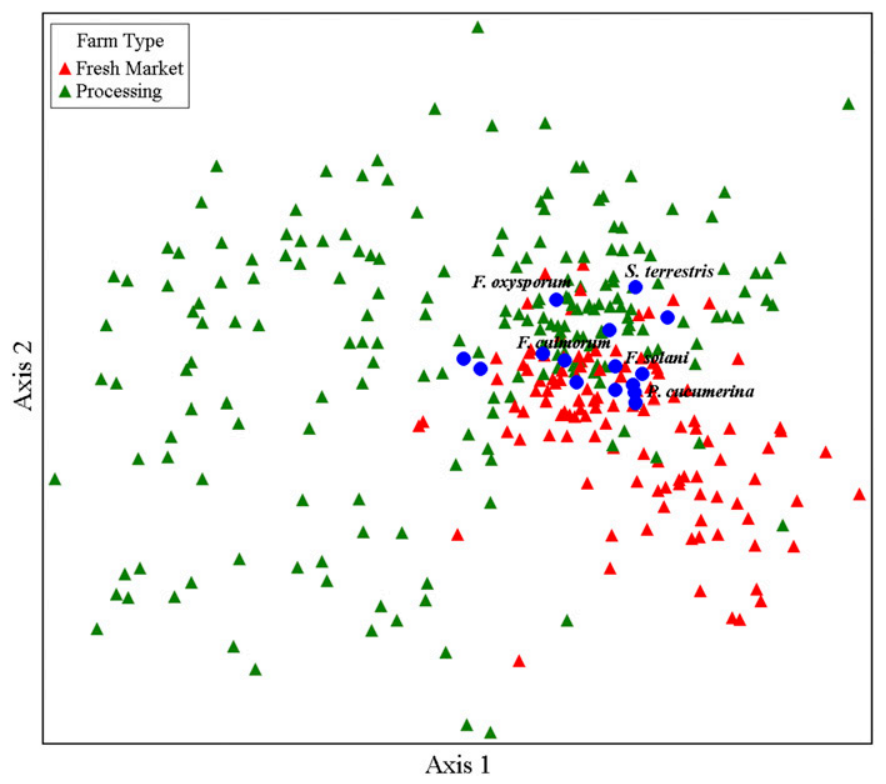

Fig. 1. Nonmetric multidimensional scaling ordination of the 35 fungal species isolated from surface disinfested tissues categorized by cucurbit crop purpose. Sampled plants were collected in surveys of commercial fields during the 2014 and 2015 growing seasons (Table 1). Red triangles represent fungal communities associated with individual plants from fresh market fields. Green triangles represent fungal communities associated with individual plants from processed vegetable fields. Blue dots show the centroid of fungal species in dimensional space with labels provided for five of the most commonly isolated fungi. Axis 1 explains 0.468 variance and axis 2 explains 0.143 variance.
PDA for 1 week, isolates were identified morphologically and photographed as described previously (photographic data were reevaluated in 2018 to confirm morphological identification). A subset of morphologically identified fungi were single-spored and a total of 1,571 isolates were selected for DNA sequencing and identification. DNA extraction using InstaGene Matrix and PCR of the ITS and EFI $\alpha$ gene regions were conducted as previously described (Accession numbers MN521460 to MN521696).

Five-year field cropping histories were obtained from advisors and growers. Fields were assigned a primary rotation crop based on the previous 5 years. Primary rotation crops were defined as grass seed ( $>2$ years in grass seed production, 19 fields), processed vegetables ( $\geq 2$ years in vegetable production, either snap bean, sweet corn, beet, peas, spinach, broccoli, cauliflower, or winter squash, 13 fields), mint ( $\geq 2$ years in mint production, 3 fields), fallow ( $\geq 2$ years in fallow or no production, 1 field), or unknown (from 13 fields from which rotation histories were not obtained). A count of the number of years previously planted in winter squash was recorded for each field $(0,1$, or 2 years out of 5$)$. Fields with unknown histories were excluded from further analyses, leaving 36 fields with known rotation history.

Growers (mostly in the north valley) with no history of squash production have been growing squash on new ground. For this reason, all fields were assigned a north or south valley designation, to assess if there was a difference in symptom severity and/or species composition between those groups. Fields were labeled north if they were located above $45^{\circ}$ latitude and south if below this latitude.

Statistical analysis of 2016 survey data. The relationship between symptom severity and crop rotation history was examined using MRPP. Each of the 1,148 plants collected in 2016 with rotation histories was entered into a primary matrix that had a column for each tissue rating. A secondary matrix had the same list of plants and four categorical variables: field, location, primary previous crop, and years previously in squash. MRPP was used to assess whether field location in the valley (south or north), primary previous crop (last 5 years), and years previously planted in squash were associated with differences in symptom severity. For example, the similarity of tissue ratings from southern fields, which are nearer to processing facilities, were compared with plants from northern fields, where squash is a more recent crop.

Symptom ratings were visualized by tissue, years in squash previously, primary rotation crop, and location in the valley using graphing methods in RStudio (version 1.1.456, RStudio Inc., Boston, MA). Histograms of symptom ratings were constructed for each host tissue to compare categories of primary previous crop and of years planted previously in squash. After review of the histograms, a $\chi^{2}$ test of independence was conducted to test similarity of isolation frequency of selected fungal species from plant tissues rated high (symptom ratings of 3 or 4) compared with those rated low (symptom ratings of 1 or 2) to determine if specific species incidence differed among these categories (McDonald 2014).

\section{RESULTS}

Condition of sampled plants in 2014 and 2015. Of the 12 fields sampled in 2014, nine fields had a history of disease and 10 showed visible wilting symptoms during the growing season (Table 1). Sixty-four percent of plants collected were symptomatic, exhibiting primary symptoms of vascular discoloration, crown rot, root rot or a combination of the three. Sixty percent of plants from processing fields were considered symptomatic, while $73 \%$ of plants from fresh market fields were symptomatic. In 2014, 4,244 isolates were identified morphologically, and 1,399 were sequenced and identified through sequence similarity in GenBank (Table 2). 
Of the seven fields sampled in 2015, six showed wilt symptoms during the growing season, and five had a history of cucurbit production in the recent past (Table 1). Forty-one percent of collected plants exhibited symptoms. Plants collected from processing vegetable fields accounted for $64 \%$ of all plants in 2015, and of those plants, $34 \%$ exhibited disease symptoms. From the $36 \%$ of plants collected in fresh market fields, $52 \%$ exhibited disease symptoms. In 2015 , with the newly developed rating scale, all plants had a mean stem discoloration rating of 1.97 out of 4 , a mean crown rating of 2.20 out of 4 , and a mean root rating of 2.38 out of 4 . Throughout the growing season, 2,050 isolates were morphologically identified, and a representative 121 isolates were subjected to DNA extraction and sequencing for molecular identification (Table 2).

Characterization of fungal communities in squash tissues. A total of 6,294 isolates were collected from 376 plants in the 2014 and 2015 growing seasons (Table 1). Of these isolates, 2,361 (56\%) in 2014 and 1,405 (70\%) in 2015 were morphologically identified as one of three Fusarium species (F. oxysporum, F. solani, and F. culmorum), P. cucumerina, or $S$. terrestris (Table 2). In both years, the fewest number of isolates were cultured from stems (23\%), but from those stem tissues, $P$. cucumerina was recovered most frequently (27\% of all stem cultures, Table 2$)$. Ten other fungal species were identified morphologically, which included Colletotrichum coccodes, Diaporthe sclerotioides, Epicoccum nigrum, and Mucorales-type fungi (Supplementary Appendix S1). In the subset of 1,520 isolates subjected to PCR analysis of the ITS and $E F 1 \alpha$ genomic regions, 86 unique fungal species were identified, and of those identified, $26 \%$ were $F$. oxysporum, $20 \%$ were $P$. cucumerina, $12 \%$ were $F$. solani, $1 \%$ were $F$. culmorum, and $4 \%$ were $S$. terrestris (Table 2), with 81 other species accounting for the remaining $37 \%$ of cultures (Supplementary Appendix S1; accession numbers MN521703 to MN521808, MN521834 to MN523210, and MN553564 to MN553577).
Fungal communities are the species that were cultured from winter squash and cucurbits in this study as grouped by one of the four environmental categories defined previously: symptomatic versus asymptomatic, cucurbit species, farm/rotation type, and tissue type. With both the morphological and molecular identifications, NMS ordinations did not suggest that fungal communities associated with symptomatic and healthy plants were strongly differentiated (data not shown). Similarly, fungal communities from the four sampled cucurbit species were not clearly differentiated by the host from which they were recovered (data not shown). $P$. cucumerina and $F$. solani, in both the morphological and molecular datasets were more strongly associated with cucurbit plants from fresh market fields compared with plants grown for processing (Fig. 1). Ordinations of specific host tissues also showed that $F$. oxysporum, $F$. solani, and $S$. terrestris were associated with crowns and roots, whereas $P$. cucumerina was associated with stems (data not shown).

Indicator species analysis found similar patterns to NMS, as well as some more specific comparisons among variables. For ISA, several fungi ( $P$. cucumerina, $F$. oxysporum, and $F$. solani) had high indicator values relative to the other species in the matrices $(36.6,47.3$, and 35, respectively, for morphological data, and 14.4, 34.3, and 14.4, respectively, for molecular data; Table 3). These indicators values, however, were not statistically associated with either diseased or healthy plants $(P>0.10)$ (Table 3$)$. With regard to cucurbit species, in the molecular dataset, $F$. solani and $P$. cucumerina were significant indicators $(P<0.04)$ of Cucumis sativus and $C$. pepo, respectively; these hosts were collected nearly exclusively from fresh market fields. In the morphological dataset, $P$. cucumerina and $S$. terrestris were both identified as significant indicators $(P<0.01)$ of $C$. moschata. $F$. solani was a significant indicator of $C$. pepo $(P<0.01)$. $P$. cucumerina and $F$. solani were identified as significant indicators $(P<0.01)$ of fresh market crops in both data sets and NMS (Table 3, NMS data not shown). In the morphological dataset, F. oxysporum and

TABLE 3

Indicator species analysis for selected fungi isolated during the 2014 and 2015 growing seasons from Cucurbita maxima, C. moschata, C. pepo, and Cucumis sativus plants collected in the Willamette Valley of Oregon

\begin{tabular}{|c|c|c|c|c|c|c|c|c|c|c|c|c|}
\hline \multirow[b]{2}{*}{ Data set ${ }^{w}$} & \multicolumn{3}{|c|}{ Diseased versus healthy } & \multicolumn{3}{|c|}{ Cucurbit species } & \multicolumn{3}{|c|}{ Crop purpose } & \multicolumn{3}{|c|}{ Host tissue } \\
\hline & Variable $^{x}$ & $\begin{array}{l}\text { Observed } \\
\text { indicator } \\
\text { value }^{y}\end{array}$ & $\begin{array}{c}P \\
\text { value }^{z}\end{array}$ & Variable & $\begin{array}{l}\text { Observed } \\
\text { indicator } \\
\text { value }\end{array}$ & $\begin{array}{c}P \\
\text { value }\end{array}$ & Variable & $\begin{array}{l}\text { Observed } \\
\text { indicator } \\
\text { value }\end{array}$ & $\begin{array}{c}P \\
\text { value }\end{array}$ & Variable & $\begin{array}{l}\text { Observed } \\
\text { indicator } \\
\text { value }\end{array}$ & $\begin{array}{c}P \\
\text { value }\end{array}$ \\
\hline \multicolumn{13}{|l|}{ Morphological } \\
\hline $\begin{array}{l}\text { Plectosphaerella } \\
\text { cucumerina }\end{array}$ & Diseased & 36.6 & 0.94 & C. moschata & 30.2 & $<0.01$ & Fresh market & 63.2 & $<0.01$ & Stem & 33.8 & $<0.01$ \\
\hline $\begin{array}{l}\text { Fusarium } \\
\text { oxysporum }\end{array}$ & Healthy & 47.3 & 0.61 & C. moschata & 27.5 & 0.28 & Processing & 62.4 & $<0.01$ & Crown & 34.7 & $<0.01$ \\
\hline F. solani & Diseased & 35 & 0.20 & C. реро & 29.9 & $<0.01$ & Fresh market & 60.4 & $<0.01$ & Crown & 21.9 & $<0.01$ \\
\hline F. culmorum & Healthy & 12.3 & 0.40 & C. pepo & 12.8 & 0.07 & Fresh market & 12.6 & 0.36 & Stem & 5.6 & 0.19 \\
\hline $\begin{array}{c}\text { Setophoma } \\
\text { terrestris }\end{array}$ & Healthy & 15.6 & 0.32 & C. moschata & 24.1 & $<0.01$ & Processing & 27.9 & $<0.01$ & Crown & 16.5 & $<0.01$ \\
\hline \multicolumn{13}{|l|}{ Molecular } \\
\hline P. cucumerina & Diseased & 14.4 & 0.99 & C. pepo & 29 & $<0.01$ & Fresh market & 48.2 & $<0.01$ & Stem & 23.8 & $<0.01$ \\
\hline F. oxysporum & Healthy & 34.3 & 0.16 & C. maxima & 18.2 & 0.61 & Fresh market & 36.8 & 0.04 & Crown & 29.1 & $<0.01$ \\
\hline F. solani & Healthy & 14.4 & 0.40 & $\begin{array}{l}\text { Cucumis } \\
\text { sativus }\end{array}$ & 16.3 & 0.04 & Fresh market & 30 & $<0.01$ & Crown & 9.7 & 0.20 \\
\hline F. culmorum & Healthy & 5.6 & 0.03 & C. pepo & 1.7 & 0.95 & Fresh market & 2.8 & 0.75 & Crown & 0.9 & 0.99 \\
\hline S. terrestris & Healthy & 5.7 & 0.12 & C. pepo & 3.5 & 0.61 & Processing & 4.3 & 0.42 & Crown & 4 & 0.08 \\
\hline \multicolumn{13}{|c|}{$\begin{array}{l}\text { w Data set used in indicator species analysis: molecularly identified fungi, or morphologically identified fungi. } \\
\text { x For each fungal species, the variable with the largest observed indicator value from the categorical group. } \\
\text { y Observed indicator value based on the relative frequency and abundance of an isolate in a specific group, out of } 100 \text {. } \\
\text { z } P \text { value from a Monte Carlo test of significance for observed indicator value compared with that expected at random. Bolded values indicate } \\
\text { statistically significant } P \text { values of } \leq 0.05 \text {. }\end{array}$} \\
\hline
\end{tabular}


$S$. terrestris were significant indicators of processing crops. As with NMS, in both data sets, $F$. oxysporum was identified as a significant indicator of crown tissue and $P$. cucumerina was identified as a significant indicator of stem tissue $(P<0.01$; Table 3$)$. In the morphological data, $F$. solani and $S$. terrestris were also significant indicators of crown tissue $(P<0.01$; Table 3$)$, which was consistent with NMS data.

Pathogenicity of selected fungal species. Inoculation of greenhouse-grown $C$. maxima 'Golden Delicious' with selected isolates of five fungal species ( F. culmorum, F. oxysporum, F. solani,

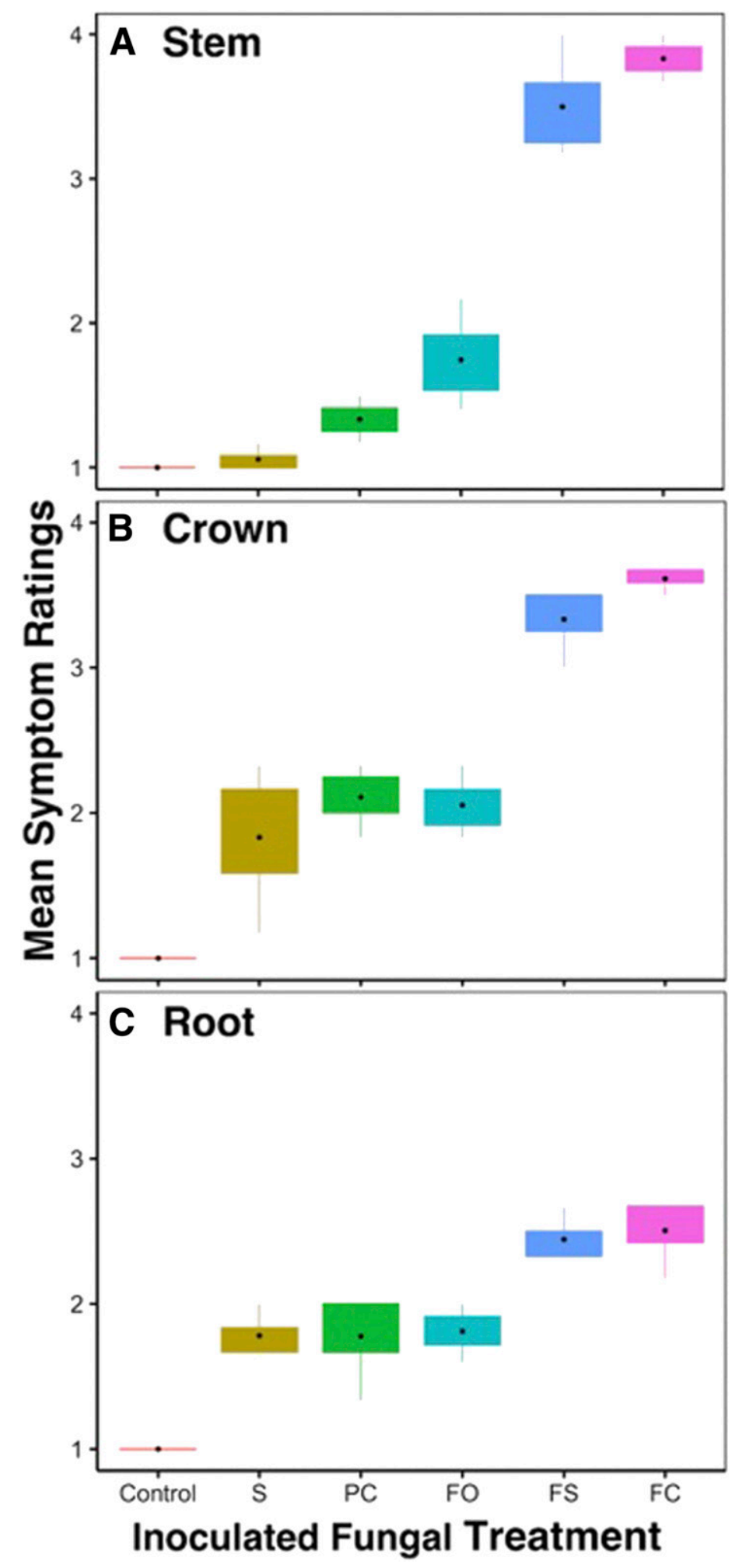

Fig. 2. Box and whisker plots showing mean symptom ratings attributable to the inoculated fungus and the mock-inoculated control in greenhouse-grown Cucurbita maxima 'Golden Delicious'. A, Stem tissue, B, crown tissue, and C, root tissue. Symptoms were rated on a 1- to 4-scale that ranged from healthy (1) to severely diseased (4). Black dots indicate mean rating. Treatment labels: $\mathrm{PC}=$ Plectosphaerella cucumerina, $\mathrm{S}=\mathrm{Setophoma}$ terrestris, $\mathrm{FO}=$ Fusarium oxysporum, $\mathrm{FS}=F$. solani, and $\mathrm{FC}=F$. culmorum . 
$P$. cucumerina, and $S$. terrestris) resulted in symptoms of disease (foliar chlorosis, stem vascular discoloration, crown and root rot) from each of the fungi. Symptom expression began as early as 6 days after inoculation with $F$. solani and $F$. culmorum. Symptom ratings of specific host tissues (root, crown, and stem) recorded at the time of foliar symptom appearance or at the end of the experiment (49 days) showed that each species could cause symptoms of disease greater than the mock-inoculated control (Fig. 2, Table 4). Using MRPP, pairwise comparisons showed that $F$. oxysporum, $S$. terrestris, and $P$. cucumerina caused significantly higher crown and root rot symptoms compared with the control but did not cause significantly higher disease symptoms in the stem vascular tissue than control treated plants (Table 4, $P<0.003$ ). F. solani and $F$. culmorum caused similarly severe disease symptoms in the stem and crown tissues (Table $4, P<0.003$ ). In root tissue, $F$. culmorum caused higher disease severity than $F$. solani $(P<0.003)$, and all fungal treatments had significantly greater disease severity than that of the mockinoculated control (Fig. 2, Table 4).

For all five fungal species treatments, reisolation from the plants onto which they were inoculated was successful from at least $66 \%$ of stems, $81 \%$ of crown, and $87 \%$ of roots. S. terrestris was the least readily recultured species, despite the roots having characteristic pink rot symptoms, and P. cucumerina was more prevalent in the crowns and roots than stem tissue. When plated, tissue pieces from $45 \%$ of control plants yielded a few fungi that matched the morphology and molecular identity of the inoculated fungi; however, the isolation plates were dominated by other fungi, including many
Penicillium-type and Mucorales-type fungi. The identity of the reisolated pathogens was confirmed by sequencing the ITS region and achieving 98 to $100 \%$ identity.

C. maxima survey with unbiased sampling and crop rotation history in 2016. In 2016, a total of 4,497 fungal isolates were identified morphologically from a subset of 264 plants (of 1,632) and 263 isolates were identified by sequencing of the ITS and EF1 $\alpha$ genomic regions (Table 5). Fourteen fungal species were identified morphologically, and 27 species were identified from sequencing (Table 1). As in the 2014-15 survey, the most common fungal species recovered were F. oxysporum (25\%), P. cucumerina (20\%), F. solani (11\%), F. culmorum (7\%), and S. terrestris (4\%) with other fungi accounting for the remainder (Supplementary Appendix S3; accession numbers MN521460 to MN521696). P. cucumerina and $S$. terrestris were recovered in greater frequencies from symptomatic than from healthy plants (Table 5). Fusarium spp., however, were cultured at the same or slightly lower rates in symptomatic than healthy plants. Compared with the other primary rotation crops, fields previously in grass seed had a greater incidence of $F$. culmorum $(9 \%$ of isolates) and $F$. solani (13\% of isolates) (Table 5). Plants within a processed vegetable primary rotation had the highest occurrence of $P$. cucumerina (26\% of isolates). As in previous years, stem tissues yielded the fewest isolates and P. cucumerina was the most common species in this tissue (Table 5).

Overall, randomly collected plants were rated as healthy. For all 1,632 plants, the mean stem rating was $1.43 \pm(\mathrm{SD}) 0.67$ (of possible 4 ), mean crown rating was $1.56 \pm 0.72$, and mean root rating was

TABLE 4

Multiresponse permutation procedure (MRPP) analysis of symptom ratings of stems, crowns, and roots from inoculated Cucurbita maxima 'Golden Delicious' plants in greenhouse pathogenicity trials

\begin{tabular}{|c|c|c|c|c|c|c|c|c|}
\hline \multirow[b]{2}{*}{ Tissue } & \multirow[b]{2}{*}{$\begin{array}{l}\text { Inoculation } \\
\text { treatment }^{y}\end{array}$} & \multirow[b]{2}{*}{$\begin{array}{l}\text { Significance } \\
\text { group }^{z}\end{array}$} & \multicolumn{6}{|c|}{ Inoculation treatment ${ }^{x}$} \\
\hline & & & $\begin{array}{l}\text { Fusarium } \\
\text { oxysporum }\end{array}$ & F. solani & $\begin{array}{c}\text { Plectosphaerella } \\
\text { cucumerina }\end{array}$ & $\begin{array}{c}F . \\
\text { culmorum }\end{array}$ & $\begin{array}{l}\text { Setophoma } \\
\text { terrestris }\end{array}$ & Control \\
\hline \multirow{4}{*}{ Stem } & F. solani & $A$ & $<0.001$ & $\ldots$ & -17.296 & -1.356 & -21.998 & -23.100 \\
\hline & P. cucumerina & B & 0.206 & $<0.001$ & $\ldots$ & -19.238 & -1.572 & -3.573 \\
\hline & F. culmorum & $A$ & $<0.001$ & 0.094 & $<0.001$ & $\ldots$ & -22.808 & -23.633 \\
\hline & Control & B & 0.004 & $<0.001$ & 0.011 & $<0.001$ & $\mathrm{Na}$ & .. \\
\hline \multirow[t]{3}{*}{ Crown } & F. oxysporum & $B$ & $\ldots$ & -7.645 & -0.268 & -10.988 & 0.413 & -12.471 \\
\hline & F. solani & A & $<0.001$ & $\ldots$ & -9.870 & -0.016 & -12.353 & -22.842 \\
\hline & P. cucumerina & B & 0.291 & $<0.001$ & $\ldots$ & -14.610 & -0.661 & -19.002 \\
\hline \multirow[t]{6}{*}{ Root } & F. oxysporum & B & $\ldots$ & -1.700 & 0.010 & -5.554 & 0.010 & -11.144 \\
\hline & F. solani & $A B$ & 0.067 & $\ldots$ & -2.957 & -0.268 & -2.957 & -18.361 \\
\hline & P. cucumerina & B & 0.338 & 0.017 & $\ldots$ & -7.324 & 0.737 & -15.297 \\
\hline & F. culmorum & A & $<0.001$ & 0.263 & $<0.001$ & $\ldots$ & -7.324 & -22.988 \\
\hline & S. terrestris & $B$ & 0.338 & 0.017 & 0.829 & $<0.001$ & $\ldots$ & -15.297 \\
\hline & Control & C & $<0.001$ & $<0.001$ & $<0.001$ & $<0.001$ & $<0.001$ & .. \\
\hline
\end{tabular}

${ }^{x}$ Values below the diagonal show $P$ value of the likelihood that the distance between the two compared groups are based on chance alone. Bolded font indicates statistically significant comparisons adjusted for multiple comparisons using a Bonferroni correction and significant at the $P \leq 0.0033$ level. Values above the diagonal show T statistic calculated based on the within-group distances. More negative values show higher separation between compared groups.

y Inoculated treatment groups used for pairwise comparisons. There were 18 plants treated in each inoculation treatment.

$z$ Significance groups as defined by pairwise MRPP $P$ values. Treatments that are not significantly different from one another have the same letter. 
$1.67 \pm 0.86$ (Table 6). Plants from fields in the southern Willamette Valley (closer to processing centers) had numerically higher root symptom ratings than plants from northern fields, but northern fields had slightly higher stem and crown symptom ratings and percentage of dead plants. Plants from fields with a history of processed vegetables had comparatively higher root rot ratings (Figs. 3 and 4) and had the highest percentage of dead plants for all prior rotation crop types (Table 6). Similarly, plants from fields that had previously been planted in winter squash twice in the last 5 years had the highest mean crown and root ratings, $1.74 \pm 0.72$ and $2.10 \pm 1.09$, respectively, and the highest percentage of dead plants. Plants from fields with mint as the primary prior rotation crop had the lowest overall disease ratings for all tissue types.

MRPP supported the above observations with statistical evidence of group differences. Fields planted in the north valley had root symptom severities that differed significantly from fields planted in the south valley $(P \leq 0.05)$ (Table 7$)$. For each squash tissue, symptom severities from fields with a primary prior rotation of processed vegetables differed significantly from fields planted previously to mint $(P \leq 0.05)$ (Table 7$)$. Similarly, the comparison of root ratings for fields not in squash in the previous 5 years differed significantly from those planted to squash once or twice $(P \leq 0.05)$.
Compared with crown and root symptoms, histograms of symptom rating distributions (Fig. 4) showed that stem tissue exhibited the least amount of variation among the environmental categories. In contrast, histograms for root symptom ratings showed the most variation with categories of "prior crop processed vegetable" or "planted to squash previously" having distributions skewed toward higher ratings relative to "other prior crops" or "not planted to squash previously." $\chi^{2}$ analysis of fungal species recovered from plants with high symptom ratings ( 3 or 4 ) compared with plants with low ratings ( 1 or 2 ) when grouped by prior primary rotation crop, also revealed differences in the frequency of recovery of some fungal species (Table 8). For the categories of prior crop processed vegetable or previously planted in squash, the frequency of recovery of $P$. cucumerina from stems and roots was significantly greater in plants with high symptom ratings compared with those with low ratings $(P \leq 0.05)$ (Table 8$)$. Similarly, frequency of recovery of $F$. solani increased in tissues with high symptom ratings compared with low symptom ratings for at least one tissue type in categories of primary prior crop processed vegetables, primary prior crop grass seed, previously planted in squash, and no squash previously $(P \leq 0.05)$ (Table 8$)$. In contrast, there were few differences among plants with high symptom ratings compared with

TABLE 5

Fungal species isolated from Cucurbita maxima plants collected from fields in Oregon's Willamette Valley during the summer of 2016 summarized by method of isolate identification ${ }^{\mathrm{u}}$

\begin{tabular}{|c|c|c|c|c|c|c|c|c|c|c|c|c|}
\hline \multirow[b]{2}{*}{ Data set } & \multirow[b]{2}{*}{$\begin{array}{l}\text { Total } \\
\text { count }\end{array}$} & \multirow[b]{2}{*}{$\begin{array}{c}\text { Total } \\
\text { percent }\end{array}$} & \multirow{2}{*}{$\begin{array}{l}\text { Number from } \\
\text { diseased } \\
\text { plants }^{w}\end{array}$} & \multirow{2}{*}{$\begin{array}{l}\text { Number } \\
\text { from } \\
\text { healthy } \\
\text { plants }^{x}\end{array}$} & \multicolumn{5}{|c|}{ Number from primary prior crop ${ }^{\vee}$} & \multirow{2}{*}{$\begin{array}{l}\text { Number } \\
\text { from } \\
\text { stem }\end{array}$} & \multirow{2}{*}{$\begin{array}{l}\text { Number } \\
\text { from } \\
\text { crown }\end{array}$} & \multirow{2}{*}{$\begin{array}{c}\text { Number } \\
\text { from } \\
\text { root }\end{array}$} \\
\hline & & & & & $\begin{array}{l}\text { Processed } \\
\text { vegetables }\end{array}$ & $\begin{array}{l}\text { Grass } \\
\text { seed }\end{array}$ & Mint & Fallow & $\mathrm{NA}^{\mathrm{y}}$ & & & \\
\hline \multicolumn{13}{|l|}{ Morphological } \\
\hline $\begin{array}{c}\text { Plectosphaerella } \\
\text { cucumerina }\end{array}$ & 867 & 19.28 & 657 & 210 & 266 & 339 & 39 & 1 & 222 & 389 & 302 & 178 \\
\hline $\begin{array}{l}\text { Fusarium } \\
\text { oxysporum }\end{array}$ & 1135 & 25.24 & 799 & 336 & 204 & 517 & 116 & 1 & 297 & 154 & 545 & 436 \\
\hline F. solani & 476 & 10.58 & 343 & 133 & 118 & 279 & 30 & 0 & 49 & 72 & 257 & 147 \\
\hline F. culmorum & 324 & 7.20 & 222 & 102 & 47 & 190 & 33 & 0 & 54 & 143 & 107 & 74 \\
\hline $\begin{array}{l}\text { Other Fusarium } \\
\text { sp. }\end{array}$ & 374 & 8.32 & 297 & 77 & 90 & 132 & 38 & 11 & 103 & 69 & 175 & 130 \\
\hline $\begin{array}{c}\text { Setophoma } \\
\text { terrestris }\end{array}$ & 169 & 3.76 & 137 & 32 & 54 & 87 & 2 & 3 & 23 & 6 & 88 & 75 \\
\hline Other fungi & 1,152 & 25.62 & 828 & 324 & 233 & 554 & 120 & 2 & 243 & 563 & 156 & 433 \\
\hline Total & 4,497 & 100 & 3,283 & 1,214 & 1,012 & 2,098 & 378 & 18 & 991 & 1,396 & 1,630 & 1,473 \\
\hline \multicolumn{13}{|l|}{ Molecular $^{z}$} \\
\hline P. cucumerina & 76 & 29 & 59 & 17 & 23 & 30 & 5 & 0 & 18 & 35 & 26 & 15 \\
\hline F. oxysporum & 80 & 30 & 54 & 26 & 15 & 38 & 4 & 2 & 21 & 11 & 41 & 28 \\
\hline F. solani & 2 & 1 & 2 & 0 & 2 & 0 & 0 & 0 & 0 & 0 & 1 & 1 \\
\hline F. culmorum & 10 & 4 & 9 & 1 & 2 & 5 & 0 & 0 & 3 & 2 & 3 & 5 \\
\hline Other Fusaria & 37 & 14 & 29 & 8 & 8 & 16 & 3 & 1 & 7 & 16 & 10 & 11 \\
\hline $\begin{array}{c}\text { Setophoma } \\
\text { terrestris }\end{array}$ & 0 & 0 & 0 & 0 & 0 & 0 & 0 & 0 & 0 & 0 & 0 & 0 \\
\hline Other fungi & 58 & 22 & 52 & 6 & 16 & 13 & 8 & 0 & 21 & 19 & 23 & 16 \\
\hline Total & 263 & 100 & 205 & 58 & 68 & 102 & 20 & 3 & 70 & 83 & 104 & 76 \\
\hline \multicolumn{13}{|c|}{$\begin{array}{l}\text { u Supplementary Appendix S1 provides information for all other fungi identified. } \\
\text { v Primary prior crop was based on rotation histories provided by crop advisors or farmers. } \\
\text { w Diseased plants received two or more ratings of } 2 \text { or at least one rating of } 3 \text { or } 4 \text {. A total of } 199 \text { plants were identified as diseased. } \\
\text { x Healthy plants received all } 1 \text { ratings or two } 1 \text { ratings plus one rating of } 2 \text {. A total of } 65 \text { plants were identified as healthy. } \\
\text { y Rotation history unknown. } \\
\text { z Isolates identified through sequencing of ITS and EF1 } \alpha \text { genes. }\end{array}$} \\
\hline
\end{tabular}


those with low ratings for $F$. oxysporum, $F$. culmorum, and S. terrestris.

\section{DISCUSSION}

A specific community of fungi was found to be associated with winter squash distributed among stem, crown, and root tissues and made up of $F$. oxysporum, F. solani, F. culmorum, $P$. cucumerina, and $S$. terrestris. These species have been identified as pathogens of cucurbits in previous studies (Chilosi et al. 2008; García-Jiménez et al. 2008; Gwynne et al. 1997; Hawthorne 1988; Ikeda et al. 2012). However, other reported cucurbit pathogens such as Acremonium spp., Monosporascus spp., Pythium spp., or Rhizopycnis spp., which have been associated with melon and cucurbit vine collapse diseases, were not detected (Aegerter et al. 2000; AlSadi et al. 2011; Armengol et al. 2003; Chilosi et al. 2008; Martyn and Miller 1996). This study demonstrated that these fungi were not exclusive to $C$. maxima-type cucurbits but occurred in all cucurbit species grown for commercial production in the Willamette Valley. Differences in fungal communities associated with winter squash grown in grass seed, processed vegetable, mint, fresh market, or fallow rotations were also observed.

The survey data presented here suggests that some fungal species consistently detected in squash tissues could be more important than others with respect to crop health and productivity. P. cucumerina was the only pathogen found consistently associated with stem tissue, and in 2016, was commonly cultured from plants with high symptom ratings. This fungus was also associated with fresh market and processed vegetable fields. However, it was not highly virulent in pathogenicity trials and did not readily replicate vascular discoloration symptoms, possibly due to the pathogenicity test being conducted only on seedlings, while survey disease ratings and cultures were collected from mature plants (Gerlagh and Blok 1988). This fungus has been studied in cucurbit collapses in Italy and Spain and there is potentially pathogenic specialization within Plectosphaerella, which at this time is not well understood
(Carlucci et al. 2012; Chilosi et al. 2008). P. cucumerina has a wide host range, having been cultured from bamboo, cabbage, endive, poplar, potatoes, soybean, sunflower, tomatoes, and other crops (Arzanlou et al. 2013; Carlucci et al. 2012; Gao et al. 2016; Garibaldi et al. 2013; Li et al. 2017; Roy 1997; Xu et al. 2014; Zhang et al. 2015), which may be why it was isolated more frequently from plants sampled from fresh market vegetable farms that have highly varied rotations. Although the field sampling and pathogenicity tests appear to be at odds, $P$. cucumerina is a complex species exhibiting a wide range of host-fungus interactions, including generating root rot, foliar blights, and leaf spots, and even occurring as an endophyte (Arzanlou et al. 2013; Carlucci et al. 2012; Gao et al. 2016; Garibaldi et al. 2013; Li et al. 2017; Su et al. 2017). It is possible that $P$. cucumerina may intensify disease symptoms when in combination with another fungus.

F. oxysporum was the species isolated most frequently from both healthy and symptomatic squash plants; however, in greenhouse pathogenicity trials, the inoculated isolates were only mildly virulent. These results may reflect that both pathogenic and nonpathogenic strains of $F$. oxysporum can be associated with roots of cucurbits (Gordon et al. 1989; Stergiopoulos and Gordon 2014). Pathogenic specialization in $F$. oxysporum (i.e., formae speciales) has been identified for other cucurbits but it has not been identified frequently in C. maxima-type squash (Edel-Hermann and Lecomte 2019). Given the high incidence of $F$. oxysporum in surfacedisinfested squash tissues, the survey results suggest it is possible that both pathogenic and nonpathogenic strains were isolated, but that the fungus was not a severe root rot pathogen without the presence of other pathogens (Gordon et al. 1989; Gwynne et al. 1997; Zuniga et al. 1997).

In the 2016 survey of randomly collected plants, $F$. solani was frequently associated with crowns and roots of plants with high symptom ratings and was highly virulent in the pathogenicity trials, however, it was recovered less commonly than $F$. oxysporum. As early as 1938 in California, $F$. solani $\mathrm{f}$. sp. cucurbitae was identified as a root, crown, and fruit rot pathogen of $C$. pepo cultivars (Gries

TABLE 6

Summary of symptom rating ( 1 to 4 scale) ${ }^{\mathrm{v}}$ in stem, crown, and root tissues of Cucurbita maxima 'Golden Delicious' plants collected from 49 fields in Oregon's Willamette Valley during the 2016 growing season

\begin{tabular}{|c|c|c|c|c|c|}
\hline Comparison & $\begin{array}{c}\text { Group } \\
\text { (number of plants) }\end{array}$ & $\begin{array}{l}\text { Mean stem rating } \\
(\mathrm{SD})\end{array}$ & $\begin{array}{l}\text { Mean crown rating } \\
\text { (SD) }\end{array}$ & $\begin{array}{l}\text { Mean root rating } \\
\text { (SD) }\end{array}$ & $\begin{array}{l}\% \text { Plants dead at } \\
\text { collection }^{\mathrm{w}}\end{array}$ \\
\hline Field location ${ }^{x}$ & South fields $(1,196)$ & $1.41(0.65)$ & $1.54(0.72)$ & $1.70(0.87)$ & $5 a$ \\
\hline \multirow[t]{2}{*}{ Primary prior crop ${ }^{y}$} & Vegetable (366) & $1.47(0.68)$ & $1.69(0.75)$ & $1.77(0.94)$ & $10 a$ \\
\hline & Grass seed (693) & $1.42(0.68)$ & $1.52(0.72)$ & $1.68(0.83)$ & $7 \mathrm{ab}$ \\
\hline \multirow[t]{3}{*}{$\begin{array}{l}\text { Years previously in squash } \\
\text { production }^{z}\end{array}$} & $\begin{array}{l}0 \text { Years in squash } \\
(932)\end{array}$ & $1.40(0.65)$ & $1.53(0.70)$ & $1.57(0.80)$ & $6 a$ \\
\hline & $\begin{array}{l}1 \text { Year in squash } \\
(247)\end{array}$ & $1.55(0.75)$ & $1.66(0.80)$ & $1.96(0.92)$ & $10 \mathrm{a}$ \\
\hline & $\begin{array}{l}2 \text { Years in squash } \\
(59)\end{array}$ & $1.38(0.53)$ & $1.74(0.72)$ & $2.10(1.09)$ & $15 a$ \\
\hline \multicolumn{6}{|c|}{$\begin{array}{l}\text { Rating scale for stem, crown, and root tissue: } 1 \text { indicates no yellowing/discoloration, } 2 \text { indicates localized yellow to orange discoloration, } 3 \text { indicates } \\
\text { localized orange to brown discoloration, and } 4 \text { indicates complete discoloration. } \\
\text { w Percentages with the same letters are not significantly different in a test of equal proportions for group comparisons. Percentages with different letters } \\
\text { are significantly different }(P \leq 0.05) \text { in a test of equal proportions for group comparisons. } \\
\text { x Field location in the Willamette Valley as defined by its relation to the } 45^{\circ} \text { latitude line. } \\
\text { y Primary prior crop as determined by } 5 \text {-year rotation history provided by growers and field representatives. } \\
\text { z Number of times that the field had been planted in winter squash during the last } 5 \text { years according to representatives. }\end{array}$} \\
\hline
\end{tabular}


1946; Snyder 1938). There are two distinct pathogen races of $F$. solani f. sp. cucurbitae that have been identified: race 1 infects roots, stems and fruit, and race 2 only infects fruit (Elmer et al. 2007; Samac and Leong 1989). The ability of this fungus to cause disease in C. maxima cultivars has been investigated in the United
States and Japan, where after root inoculation, $C$. maxima cultivars were observed to be more susceptible than cultivars of $C$. moschata, C. pepo, and Cucumis sativus (Nagao et al. 1994; Samac and Leong 1989). Nonetheless, while $C$. maxima is one of the more susceptible cucurbit hosts of $F$. solani, most recent investigations have focused

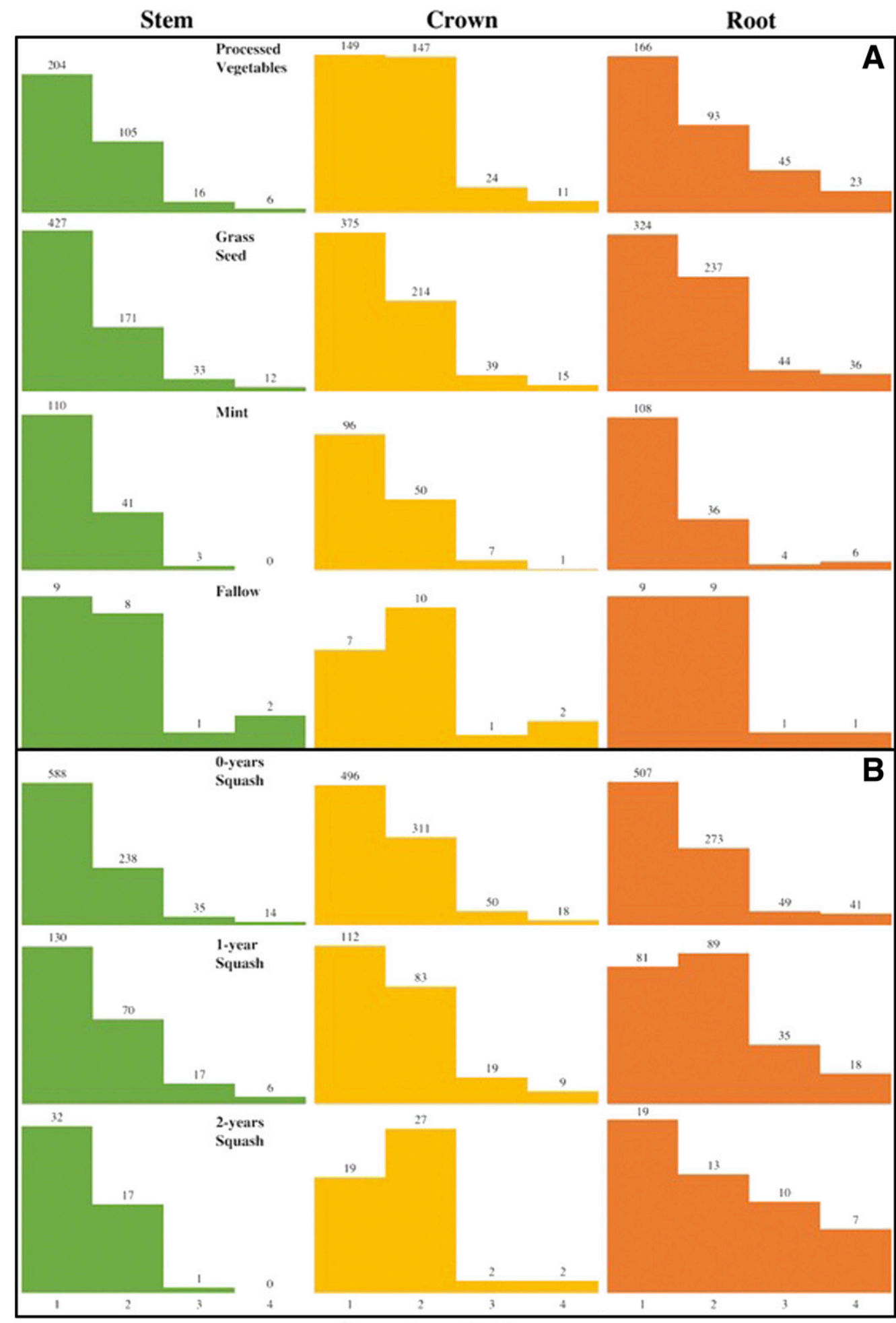

Symptom Rating

Fig. 3. Histograms of symptom ratings of stems, crowns, and roots of Cucurbita maxima 'Golden Delicious' plants sampled from fields in the Willamette Valley of Oregon in 2016 categorized by grouping factors of A, primary prior crop and B, number of years of previous 5 years the field was planted to squash. Symptoms were rated on a 1- to 4-scale that ranged from healthy (1) to severely diseased (4). Numbers above each bar are counts of the number of plants in each rating group. 
on C. pepo (Mehl and Epstein 2007). Because F. solani can be infective on other cucurbit hosts, this may explain its stronger association with fresh market fields, particularly those that produce multiple species of cucurbits on shorter rotations. F. solani has the potential to be an economically relevant pathogen in winter squash production in Oregon, but it was not as commonly recovered from surveyed symptomatic plants, suggesting the need for another pathogen to be present for adequate virulence (Mehl and Epstein 2007; Zhang et al. 2006).

F. culmorum was not as commonly cultured as the other Fusarium species but was associated with grass seed fields, which is a very common rotation crop in the Willamette Valley. Grass
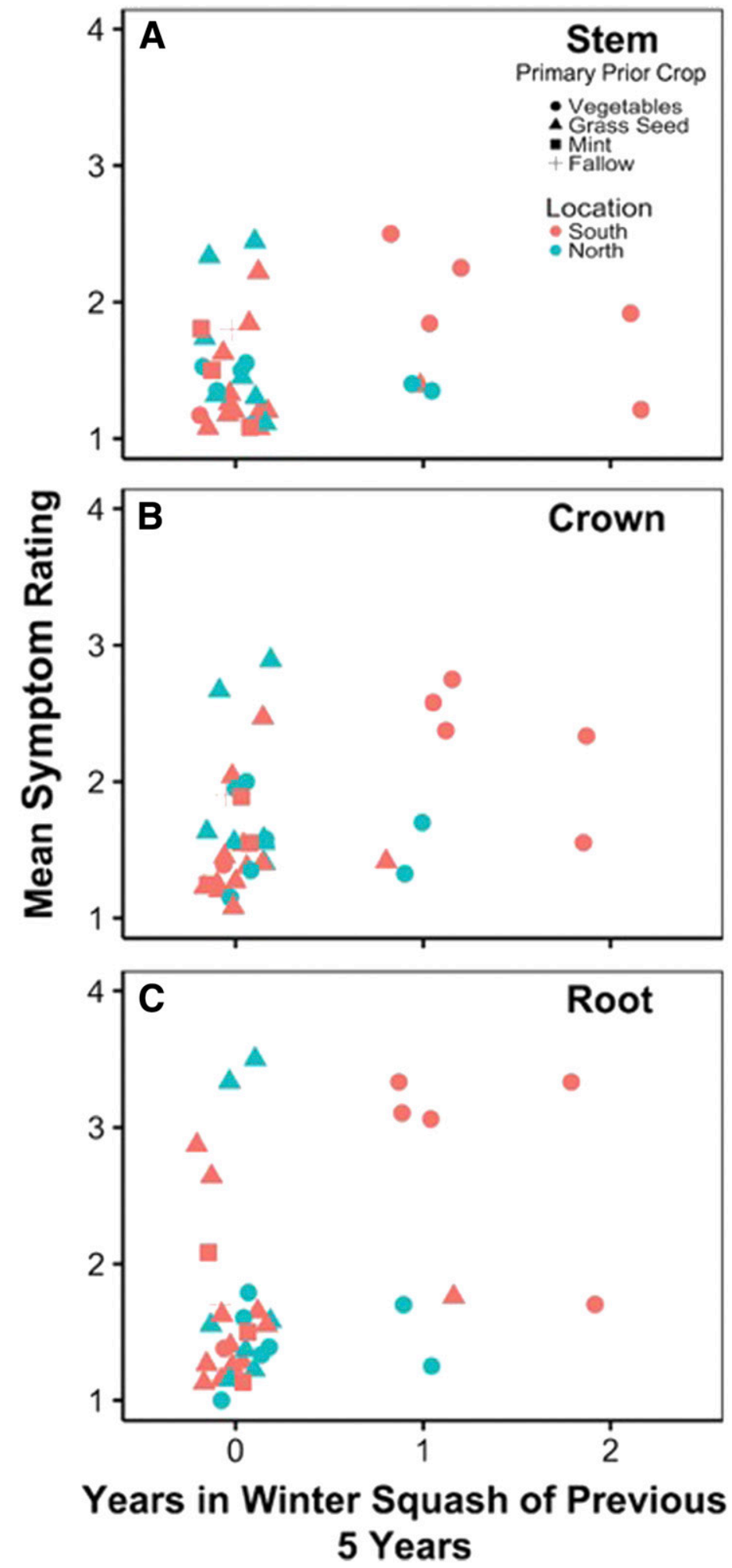

Fig. 4. Mean symptom ratings for A, stem, B, crown, and C, root tissues on a 1 (healthy) to 4 (diseased) disease severity scale from plants of Cucurbita maxima 'Golden Delicious' collected in 2016 compared with the number of years the field was planted in squash in the last 5 years. Shapes represent primary prior crop and colors represent the location (north or south of the $45^{\circ}$ latitude line) in the Willamette Valley of Oregon. 
species are common hosts of F. culmorum, where it causes important diseases such as Fusarium head blight (Leslie and Summerell 2006). F. culmorum has been identified as a causal agent of postharvest fruit rot of winter squash (Hawthorne 1988; Rivedal et al. 2018a). F. culmorum was highly virulent in the greenhouse pathogenicity trials conducted in this study on seedlings. The higher incidence of this organism in fields cropped previously to grass seed may be why some squash fields had relatively higher symptom ratings despite no recent history of squash or other vegetables. The data from mature plant surveys and greenhouse bioassays were conflicting, likely due to the fact that the disease in the field is a mature plant disease and not a seedling disease, which changes cucurbit susceptibility (Gerlagh and Blok 1988).

S. terrestris was associated with a pink root rot symptom on squash, which was replicated in the greenhouse pathogenicity experiment. Compared with severe symptoms caused by $F$. solani and $F$. culmorum, symptoms caused by $S$. terrestris were relatively minor and the pathogen did not kill any of the inoculated plants. This pathogen causes pink root in other vegetable crops, notably Allium spp., and has been described as a pathogen of cucurbits in Japan and the United States (De Gruyter et al. 2010; Ikeda et al. 2012; Rivedal et al. 2018b). The survey data and pathogenicity trial suggest that $S$. terrestris is probably not a major pathogen of C. maxima on its own. The survey results, however, leave open the question that the five most common fungi may take on greater significance when they co-occur in a host.

Unsurprisingly, previously planted crop was at least a partial predictor of symptom severity, and like others (Rowe and Powelson 2002; Stergiopoulos and Gordon 2014), the present study found that crop rotation patterns contributed to an increase or decrease in certain fungal species. Specifically, those fields that had been planted in fresh market or processing vegetable rotations had an increase in occurrence of $F$. solani and P. cucumerina, while grass

TABLE 7

Multiresponse permutation procedure (MRPP) analysis of symptom ratings of stems, crowns, and roots from survey of Cucurbita maxima 'Golden Delicious' plants collected from fields in Oregon's Willamette Valley in 2016

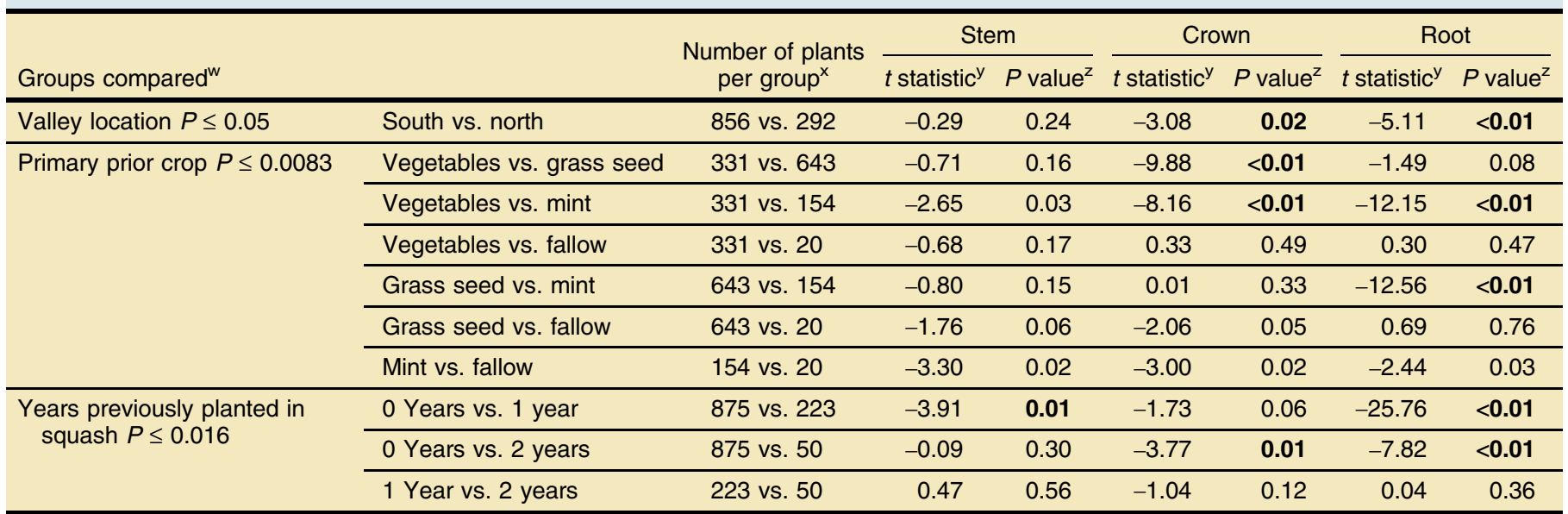

w Groups compared in MRPP analysis, same as those defined for nonmetric multidimensional scaling comparisons.

$x$ Number of plants being compared in each specified group with MRPP.

y $t$ statistic calculated based on the within-group distances. More negative values show higher separation between compared groups.

z $P$ value from a Monte Carlo test of significance for observed indicator value compared with that expected at random. Bolded values indicate statistically significant $P$ values of $\leq 0.05$.

TABLE 8

$P$ values from $\chi^{2}$ tests of independence for selected fungal species isolated in 2016 from Cucurbita maxima 'Golden Delicious' plants ${ }^{\mathrm{u}}$ with low symptom ratings compared with plants with high symptom ratings ${ }^{v}$ categorized by primary prior crop and by if the fields were planted to squash in the last 5 years ${ }^{w}$

\begin{tabular}{|c|c|c|c|c|c|c|c|c|c|c|c|c|c|c|c|c|}
\hline \multirow[b]{2}{*}{ Isolate } & \multicolumn{4}{|c|}{ Grass seed } & \multicolumn{4}{|c|}{ Vegetables } & \multicolumn{4}{|c|}{ No squash previously } & \multicolumn{4}{|c|}{$\begin{array}{c}\text { Previously planted in } \\
\text { squash }^{\times}\end{array}$} \\
\hline & Stem $^{y}$ & Crown ${ }^{y}$ & $\operatorname{Root}^{y}$ & Total $^{z}$ & Stem & Crown & Root & Total & Stem & Crown & Root & Total & Stem & Crown & Root & Total \\
\hline Fusarium oxysporum & 0.44 & 0.30 & 0.45 & 0.32 & 0.02 & 0.37 & 0.459 & 0.03 & 0.90 & 0.93 & 0.87 & 0.97 & 0.04 & 0.16 & $<0.01$ & $<0.01$ \\
\hline F. solani & 0.24 & 0.04 & $<0.01$ & $<0.01$ & 0.92 & $<0.01$ & 0.01 & $<0.01$ & 0.09 & 0.22 & $<0.01$ & $<0.01$ & $<0.01$ & 0.10 & 0.91 & $<0.01$ \\
\hline Setophoma terrestris & 0.78 & 0.42 & 0.37 & 0.46 & 0.38 & 0.55 & 0.75 & 0.54 & 0.59 & 0.17 & 0.16 & 0.13 & 0.25 & 0.02 & 0.04 & $<0.01$ \\
\hline
\end{tabular}


seed as a prior crop had an increase in occurrence of $F$. culmorum. For both primary prior rotation crop and years previously planted in squash, the 2016 survey results showed that incidence of $F$. solani and $P$. cucumerina in the fungal community increased in plants with high symptom ratings compared with plants with low ratings. These fungal species may be necessary members of the community for disease development in winter squash.

Because this study was unable to show a large difference between the fungal communities of symptomatic and healthy plants, it is possible that unknown environmental and/or edaphic factors also contribute to symptom expression. For example, in Indiana, Makam et al. (2005) found that cultural conditions such as planting into plastic mulch, low $\mathrm{pH}$, low organic matter, and preemergent herbicide treatments resulted in lower root fresh weight and vine decline symptoms when no causal agent could be identified in watermelon. Additionally, atmospheric and soil temperature are known to enhance soilborne melon collapse caused by Monosporascus cannonballus and Acremonium cucurbitacearum in Texas and Israel (Bruton et al. 1999; Pivonia et al. 2002). Temperature at planting and during stressful periods within the growing season, such as fruit set, may also contribute to incidence and severity of winter squash decline (Bruton et al. 1999). Another potential driver of root rot disease severity in the Willamette Valley could relate to water use (AlMawaali et al. 2013; Pivonia et al. 1997). Most winter squash farmers apply overhead irrigation water throughout the season. In potato, Powelson and Rowe (1993) showed that potato early dying symptom severity late in the season was enhanced by excessive soil moisture early in the season, and that both symptoms and yield losses could be reduced by imposing mild drought stress conditions in the period before tuber initiation. Current investigations are being conducted on whether mild drought stress prior to fruit set in winter squash can reduce root rot disease severity.

This study relied on culturable fungi as a basis for the short list of potential pathogens causing winter squash decline because of the similarity in symptoms to previously mentioned cucurbit declines. Due to these methods, it is possible that a causal agent was not captured, such as a bacterial, obligate, or oomycete pathogen. However, in intensive pathogenicity trials that incorporated mixed inoculum sources, symptoms like those seen in the field were recreated, suggesting that this is a problem caused by the fungi collected in these surveys (H. M. Rivedal, A. G. Stone, J. F. Tabima, and K. B. Johnson, unpublished data).

Until recently, winter squash has not been a common rotation crop for grass seed or processed vegetable producers of the Willamette Valley. For example, in this effort, most (78\%) surveyed fields with rotation histories had less than 1 year of squash production in the last 5 years. In spite of this, unhealthy plants were found in every surveyed field, and rotation crops did affect the prevalence of certain fungi associated with winter squash. Consequently, this study clearly indicates squash yield decline is a complex problem and that crop performance is difficult to predict due to the involvement of several potential pathogens and the potential contribution of several environmental factors. Importantly, this effort provides a framework on which to base future investigations into causal agent pathogens and management strategies to ameliorate this problem.

\section{ACKNOWLEDGMENTS}

We thank the crop advisors from Stahlbush Island Farms and Autumn Seed for providing farmer contacts and field recommendations; winter squash growers for access to their land and rotation history records; greenhouse operations staff at the OSU West Greenhouses for their technical support of the pathogenicity trials; members of the Johnson and Stone labs, specifically Todd N. Temple,
Evan C. Thompson, Victoria V. Smith, Brandon L. Ferington, Mora A. Camplair, and Gabriella M. Boyer, for their technical assistance with inoculations and data collection; and Duncan R. Kroese for technical assistance with data collection and general support.

\section{LITERATURE CITED}

Aegerter, B. J., Gordon, T. R., and Davis, R. M. 2000. Occurrence and pathogenicity of fungi associated with melon root rot and vine decline in California. Plant Dis. 84:224-230.

Al-Mawaali, Q., Al-Sadi, A., Al-Said, F., and Deadman, M. 2013. Etiology, development and reaction of muskmelon to vine decline under arid conditions of Oman. Phytopathol. Mediterr. 52:457-465.

Al-Sadi, A. M., Al-Said, F. A., Al-Kiyumi, K. S., Al-Mahrouqi, R. S., AlMahmooli, I. H., and Deadman, M. L. 2011. Etiology and characterization of cucumber vine decline in Oman. Crop Prot. 30:192-197.

Armengol, J., Vicent, A., Martínez-Culebras, P., Bruton, B. D., and GarcíaJiménez, J. 2003. Identification, occurrence and pathogenicity of Rhizopycnis vagum on muskmelon in Spain. Plant Pathol. 52:68-73.

Arzanlou, M., Torbati, M., and Khodaei, S. 2013. Phenotypic and molecular characterization of Plectosphaerella cucumerina on bamboo from Iran. Mycosphere 4:647-651.

Bruton, B. D., Garcia-Jimenez, J., and Armengol, J. 1999. Analysis of the relationship between temperature and vine declines caused by Acremonium cucurbitacearum and Monosporascus cannonballus on muskmelon. Subtrop. Plant Sci. 51:23-28.

Carlucci, A., Raimondo, M. L., Santos, J., and Phillips, A. J. L. 2012. Plectosphaerella species associated with root and collar rots of horticultural crops in southern Italy. Persoonia 28:34-48.

Champaco, E. R., Martyn, R. D., and Miller, M. E. 1993. Comparison of Fusarium solani and $F$. oxysporum as causal agents of fruit rot and root rot of muskmelon. HortScience 28:1174-1177.

Chilosi, G., Reda, R., Aleandri, M. P., Camele, I., Altieri, L., Montuschi, C., Languasco, L., Rossi, V., Agosteo, G. E., Macrì, C., Carlucci, A., Lops, F., Mucci, M., Raimondo, M. L., and Frisullo, S. 2008. Fungi associated with root rot and collapse of melon in Italy. EPPO Bull. 38:147-154.

Ciardo, D., Schär, G., Böttger, E., Altwegg, M., and Bosshard, P. 2006. Internal transcribed spacer sequencing versus biochemical profiling for identification of medically important yeasts. J. Clin. Microbiol. 44:77-84.

De Gruyter, J., Woudenberg, J. H. C., Aveskamp, M. M., Verkley, G. J. M., Groenewald, J. Z., and Crous, P. W. 2010. Systematic reappraisal of species in Phoma section Paraphoma, Pyrenochaeta and Pleurophoma. Mycologia 102:1066-1081.

Dufrene, M., and Legendre, P. 1997. Species assemblages and indicator species: The need for a flexible asymmetrical approach. Ecol. Monogr. 67:345-366.

Dugan, F. M. 2006. The Identification of Fungi: An Illustrated Introduction with Keys, Glossary, and Guide to Literature. American Phytopathological Society, St. Paul, MN.

Edel-Hermann, V., and Lecomte, C. 2019. Current status of Fusarium oxysporum formae speciales and races. Phytopathology 109:512-530.

Elmer, W. H., Covert, S. F., and O'Donnell, K. 2007. Investigation of an outbreak of Fusarium foot and fruit rot of pumpkin within the United States. Plant Dis. 91:1142-1146.

Fitt, B. D. L., Huang, Y. J., Bosch, F. V. D., and West, J. S. 2006. Coexistence of related pathogen species on arable crops in space and time. Annu. Rev. Phytopathol. 44:163-182.

Gao, J., Zhang, Y. Y., Zhao, X. J., Wang, K., and Zhao, J. 2016. First report of potato wilt caused by Plectosphaerella cucumerina in inner Mongolia, China. Plant Dis. 100:2523.

García-Jiménez, J., Armengol, J., Moya, M. J., and Sales, R., Jr. 1997. First report of Fusarium solani f. sp. cucurbitae Race 1 in Spain. Plant Dis. 81:1216.

García-Jiménez, J., Armengol, J., Sales, R., Jordá, R., and Bruton, B. D. 2008. Fungal pathogens associated with melon collapse in Spain. EPPO Bull. 30:169-173.

Garibaldi, A., Gilardi, G., Ortu, G., and Gullino, M. L. 2013. First report of a new leaf spot caused by Plectosphaerella cucumerina on field grown endive (Cichorium endivia) in Italy. Plant Dis. 97:848.

Gerlagh, M., and Blok, W. J. 1988. Fusarium oxysporum f.sp. cucurbitacearum n.f. embracing all formae speciales of $F$. oxysporum attacking Cucurbitaceous crops. Neth. J. Plant Pathol. 94:17-31.

Gordon, T. R., Okamoto, D., and Jacobson, D. J. 1989. Colonization of muskmelon and non-susceptible crops by Fusarium oxysporum f. sp. melonis and other species of Fusarium. Phytopathology 79:1095-1100. 
Gries, G. A. 1946. Physiology of Fusarium foot rot of squash. Conn. Agric. Exp. Stn. Bull. 500:1-19.

Griffin, D., Kellogg, C., Peak, K., and Shinn, E. 2002. A rapid and efficient assay for extracting DNA from fungi. Lett. Appl. Microbiol. 34:210-214.

Gwynne, B. J., Gordon, T. R., and Davis, R. M. 1997. A new race of Fusarium oxysporum f. sp. melonis causing Fusarium wilt of muskmelon in the Central Valley of California. Plant Dis. 81:1095.

Hawthorne, B. T. 1988. Fungi causing storage rots on fruit of Cucurbita spp. N.Z. J. Exp. Agric. 16:151-157.

Ikeda, K., Kuwabara, K., Urushibara, T., Soyai, P., Miki, S., and Shibata, S. 2012. Pink root rot of squash caused by Setophoma terrestris in Japan. J. Gen. Plant Pathol. 78:372-375.

Kruskal, J. B. 1964. Nonmetric multidimensional scaling: A numerical method. Psychometrika 29:115-129.

Lamichhane, J. R., and Venturi, V. 2015. Synergisms between microbial pathogens in plant disease complexes: A growing trend. Front. Plant Sci. 6:385.

Le May, C., Potage, G., Andrivon, D., Tivoli, B., and Outreman, Y. 2009. Plant disease complex: Antagonism and synergism between pathogens of the Ascochyta blight complex on pea. J. Phytopathol. 157:715-721.

Leslie, J. F., and Summerell, B. A. 2006. The Fusarium Laboratory Manual. Blackwell Publishing, Ames, IA.

Li, P. L., Chai, A. L., Shi, Y. X., Xie, X. W., and Li, B. J. 2017. First report of root rot caused by Plectosphaerella cucumerina on cabbage in China. Mycobiology 45:110-113.

Makam, S. N., Peer, W. A., Blakeslee, J. J., and Murphy, A. S. 2005. Cultural conditions contributing to vine decline syndrome in watermelon. HortScience 40:597-601.

Martyn, R. D., and Miller, M. E. 1996. Monosporascus root rot and vine decline: An emerging disease of melons worldwide. Plant Dis. 80:716-725.

Mather, P. M. 1976. Computational Methods of Multivariate Analysis in Physical Geography. John Wiley \& Sons, London.

McCune, B., and Grace, J. B. 2002. Analysis of Ecological Communities. MjM Software, Gleneden Beach, OR.

McCune, B., and Mefford, M. J. 1999. Multivariate Analysis of Ecological Data, Version 4.0. MjM Software, Gleneden Beach, OR.

McDonald, J. H. 2014. Handbook of Biological Statistics, 3rd ed. Sparky House Publishing, Baltimore, MD.

Mehl, H. L., and Epstein, L. 2007. Identification of Fusarium solani f. sp. cucurbitae race 1 and race 2 with PCR and production of disease-free pumpkin seeds. Plant Dis. 91:1288-1292.

Mertely, J. C., Martyn, R. D., Miller, M. E., and Bruton, B. D. 1991. Role of Monosporascus cannonballus and other fungi in a root rot/vine decline disease of muskmelon. Plant Dis. 75:1133-1137.

Mielke, P. W., Berry, K. J., and Brier, G. W. 1981. Application of multi-response permutation procedures for examining seasonal changes in monthly sea-level pressure patterns. Mon. Weather Rev. 109:120-126.

Nagao, H., Sato, K., and Ogiwara, S. 1994. Susceptibility of Cucurbita spp. to the cucurbit root rot fungus, Fusarium solani f. sp. cucurbitae race 1. Agronomie 14:95-102.

Pivonia, S., Cohen, R., Kafkafi, U., Ben Ze'ev, I. S., and Katan, J. 1997. Sudden wilt of melons in southern Israel: Fungal agents and relationship with plant development. Plant Dis. 81:1264-1268.

Pivonia, S., Cohen, R., Kigel, J., and Katan, J. 2002. Effect of soil temperature on disease development in melon plants infected by Monosporascus cannonballus. Plant Pathol. 51:472-479.
Powelson, M. L., and Rowe, R. C. 1993. Biology and management of early dying of potatoes. Annu. Rev. Phytopathol. 31:111-126.

Punja, Z. K., and Parker, M. 2000. Development of Fusarium root and stem rot, a new disease on greenhouse cucumber in British Columbia, caused by Fusarium oxysporum f. sp. radicis-cucumerinum. Can. J. Plant Pathol. 22: 349-363.

Rivedal, H. M., Stone, A. G., and Johnson, K. B. 2018a. First report of Fusarium culmorum causing fruit rot of winter squash (Cucurbita maxima) in Oregon. Plant Dis. 102:2659.

Rivedal, H. M., Stone, A. G., and Johnson, K. B. 2018b. First report of Setophoma terrestris causing pink root rot of winter squash (Cucurbita maxima) in Oregon. Plant Dis. 102:2661.

Rowe, R. C., and Powelson, M. L. 2002. Potato early dying: Management challenges in a changing production environment. Plant Dis. 86: 1184-1193.

Roy, K. W. 1997. Fusarium solani on soybean roots: Nomenclature of the causal agent of sudden death syndrome and identity and relevance of $F$. solani form B. Plant Dis. 81:259-266.

Samac, D. A., and Leong, S. A. 1989. Disease development in Cucurbita maxima (squash) infected with Fusarium solani f. sp. cucurbitae. Can. J. Bot. 67:3486-3489.

Shaffer, J. P. 1995. Multiple hypothesis testing. Annu. Rev. Psychol. 46: 561-584.

Snyder, W. C. 1938. Fusarium foot rot of Cucurbita. Phytopathology 28:19.

Steel, R., Torri, J., and Dickey, D. 1997. Principles and Procedures of Statistics: A Biometrical Approach. McGraw-Hill, New York.

Stergiopoulos, I., and Gordon, T. R. 2014. Cryptic fungal infections: The hidden agenda of plant pathogens. Front. Plant Sci. 5:506.

Su, L., Deng, H., and Niu, Y. C. 2017. Phylogenetic analysis of Plectosphaerella species based on multi-locus DNA sequences and description of $P$. sinensis sp. nov. Mycol. Prog. 16:823-829.

Taylor, A., and Losh, D. J. 2018. Oregon Agripedia. Oregon Department of Agriculture, Salem, OR.

Vitale, S., Maccaroni, M., and Belisario, A. 2007. First report of zucchini collapse by Fusarium solani f. sp. cucurbitae race 1 and Plectosporium tabacinum in Italy. Plant Dis. 91:325.

White, T. J., Bruns, T., Lee, S., and Taylor, J. W. 1990. Amplification and direct sequencing of fungal ribosomal RNA genes for phylogenetics. Pages 315-322 in: PCR Protocols: A Guide to Methods and Applications. Academic Press, New York.

Xu, J., Xu, X., Cao, Y., and Zhang, W. 2014. First report of greenhouse tomato wilt caused by Plectosphaerella cucumerina in China. Plant Dis. 98:158.

Zhang, N., O’Donnell, K., Sutton, D. A., Nalim, F. A., Summerbell, R. C., Padhye, A. A., and Geiser, D. M. 2006. Members of the Fusarium solani species complex that cause infections in both humans and plants are common in the environment. J. Clin. Microbiol. 44:2186-2190.

Zhang, Y. Y., Li, M., Liang, Y., Zhou, H. Y., and Zhao, J. 2015. First report of sunflower wilt caused by Plectosphaerella cucumerina in China. Plant Dis. 99:1646.

Zuniga, T. L., Zitter, T. A., Gordon, T. R., Schroeder, D. T., and Okamoto, D. 1997. Characterization of pathogenic races of Fusarium oxysporum f. sp. melonis causing Fusarium wilt of melon in New York. Plant Dis. 81: 592-596. 